\title{
Novel Tailoring Reaction for Two Adjacent Coordinated Nitriles Giving Platinum 1,3,5-Triazapentadiene Complexes
}

\author{
Pavel V. Gushchin, ${ }^{\dagger}$ Marina R. Tyan, ${ }^{\dagger}$ Nadezhda A. Bokach, ${ }^{\dagger}$ Mikhail D. Revenco, ${ }^{\ddagger}$ Matti Haukka, ${ }^{\S}$ \\ Meng-Jiy Wang, ${ }^{\perp}$ Cheng-Hsuan Lai, ${ }^{,}$Pi-Tai Chou, ${ }^{*, \emptyset}$ and Vadim Yu. Kukushkin ${ }^{*,+, \|}$ \\ St. Petersburg State University, 198504 Stary Petergof, Russian Federation, Department of \\ Chemistry, State University of Moldova, MD 2009 Chisinau, Republic of Moldova, Institute of \\ Macromolecular Compounds of the Russian Academy of Sciences, Bolshoii Pr. 31, \\ 199004 St. Petersburg, Russian Federation, Department of Chemistry, University of Joensuu, \\ P.O. Box 111, FI-80101 Joensuu, Finland, Department of Chemical Engineering, National Taiwan \\ University of Science and Technology, 43, Keelung Road, Section 4, Taipei, 106 Taiwan, and \\ Department of Chemistry, National Taiwan University, No. 1, Roosevelt Road, Section 4, Taipei, Taiwan
}

Received December 22, 2007

\begin{abstract}
The tailoring reaction of the two adjacent nitrile ligands in cis-[ $\left.\mathrm{PtCl}_{2}(\mathrm{RCN})_{2}\right]\left(\mathrm{R}=\mathrm{Me}, \mathrm{Et}, \mathrm{CH}_{2} \mathrm{Ph}, \mathrm{Ph}\right)$ and $\left[\mathrm{Pt}(\mathrm{tmeda})\left(\mathrm{EtCN}_{2}\right)_{2}\left[\mathrm{SO}_{3} \mathrm{CF}_{3}\right]_{2}\left(\mathbf{8} \cdot(\mathrm{OTf})_{2} ;\right.\right.$ tmeda $=\mathrm{N}, \mathrm{N}, \mathrm{N}^{\prime}, \mathrm{N}^{\prime}$-tetramethylethylenediamine) upon their interplay with $\mathrm{N}, \mathrm{N}^{\prime}$-diphenylguanidine (DPG; $\left.\mathrm{NH}=\mathrm{C}(\mathrm{NHPh})_{2}\right)$, in a 1:2 molar ratio gives the 1,3,5-triazapentadiene complexes $\left[\mathrm{PtCl}_{2}\{\mathrm{NHC}(\mathrm{R}) \mathrm{NHC}(\mathrm{R})=\mathrm{NH}\}\right](1-4)$ and $[\mathrm{Pt}(\mathrm{tmeda})\{\mathrm{NHC}(\mathrm{Et}) \mathrm{NHC}(\mathrm{Et}) \mathrm{NH}\}]\left[\mathrm{SO}_{3} \mathrm{CF}_{3}\right]_{2}\left(10 \cdot(\mathrm{OTf})_{2}\right)$, respectively. In contrast to the reaction of $\mathbf{8} \cdot(\mathrm{OTf})_{2}$ with $\mathrm{NH}=\mathrm{C}(\mathrm{NHPh})_{2}$, interaction of $\mathbf{8} \cdot(\mathrm{OTf})_{2}$ with excess gaseous $\mathrm{NH}_{3}$ leads to formation of the platinum(II) bis(amidine) complex cis-[Pt(tmeda) $\left\{\mathrm{NH}=\mathrm{C}\left(\mathrm{NH}_{2}\right) \mathrm{Et}_{2}\right]\left[\mathrm{SO}_{3} \mathrm{CF}_{3}\right]_{2}\left(\mathbf{9} \cdot(\mathrm{OTf})_{2}\right)$. Treatment of trans-[PtCl$\left(\mathrm{RCN}_{2}\right]\left(\mathrm{R}=\mathrm{Et}, \mathrm{CH}_{2} \mathrm{Ph}, \mathrm{Ph}\right)$ with 2 equiv of $\mathrm{NH}=\mathrm{C}(\mathrm{NHPh})_{2}$ in $\mathrm{EtCN}(\mathrm{R}=\mathrm{Et})$ and $\mathrm{CH}_{2} \mathrm{Cl}_{2}(\mathrm{R}=$ $\left.\mathrm{CH}_{2} \mathrm{Ph}, \mathrm{Ph}\right)$ solutions at $20-25^{\circ} \mathrm{C}$ leads to $[\mathrm{PtCl}\{\mathrm{NH}=\mathrm{C}(\mathrm{R}) \mathrm{NC}(\mathrm{NHPh})=\mathrm{NPh}\}(\mathrm{RCN})](11-13)$. When any of the trans- $\left.\mathrm{PtCl}_{2}(\mathrm{RCN})_{2}\right]\left(\mathrm{R}=\mathrm{Et}, \mathrm{CH}_{2} \mathrm{Ph}, \mathrm{Ph}\right)$ complexes reacts in the corresponding nitrile $\mathrm{RCN}$ with 4 equiv of $\mathrm{DPG}$ at prolonged reaction time $\left(75^{\circ} \mathrm{C}, 1-2\right.$ days), complexes containing two bidentate 1,3,5-triazapentadiene ligands, i.e. $\left[\mathrm{Pt}\{\mathrm{NH}=\mathrm{C}(\mathrm{R}) \mathrm{NC}(\mathrm{NHPh})=N \mathrm{Ph}\}_{2}\right](14-16)$, are formed. Complexes 14-16 exhibit strong phosphorescence in the solid state, with quantum yields (peak wavelengths) of $0.39(530 \mathrm{~nm}), 0.61(460 \mathrm{~nm})$, and $0.74(530 \mathrm{~nm})$, respectively. The formulation of the obtained complexes was supported by satisfactory $\mathrm{C}, \mathrm{H}$, and $\mathrm{N}$ elemental analyses, in agreement with FAB-MS, ESI-MS, IR, and ${ }^{1} \mathrm{H}$ and ${ }^{13} \mathrm{C}\left\{{ }^{1} \mathrm{H}\right\}$ NMR spectra. The structures of $1,2,4,11$, $13,14,9 \cdot(\text { picrate })_{2}$, and $10 \cdot(\text { picrate })_{2}$ were determined by single-crystal X-ray diffraction.
\end{abstract}

\section{Introduction}

1,3-Dicarbonyl derivatives (Chart $1, \mathbf{A}$ ) in general and acetylacetone in particular represent one of the oldest and, concurrently, one of the most valuable classes of ligands for metal ion chelation with a substantial fraction of the elements in the periodic table. The rich chemistry of these species is well-documented, and a good number of industrial applica-

* Author to whom correspondence should be addressed. E-mail: kukushkin@vk2100.spb.edu.

St. Petersburg State University.

" Institute of Macromolecular Compounds of the Russian Academy of Sciences.

$¥$ State University of Moldova.

$\S$ University of Joensuu.

${ }^{\perp}$ National Taiwan University of Science and Technology.

II National Taiwan University. tions are known. ${ }^{1}$ The dinitrogen analogues of 1,3-dicarbonyl compounds, i.e. 1,5-diazapentadienyl (or $\beta$-diketiminate) species (B), have been much less studied but over the past decade they have fast become one of the most useful groups of monoanionic nitrogen-based ligands in chemistry. Their complexes serve as useful models for synthetic, reactivity, and structural investigations ${ }^{2-5}$ and also for modeling active sites of metalloenzymes. ${ }^{6}$ In addition, $\beta$-diketiminates of

(1) Pettinari, C.; Marchetti, F.; Drozdov, A. $\beta$-Diketones and Related Ligands. In Comprehensive Coordination Chemistry, 2nd ed.; Elsevier: Amsterdam, 2004; Vol. 1, Chapter 1.6, pp 97-115.

(2) (a) Piers, W.; Emslie, D. J. H. Coord. Chem. Rev. 2002, 131, 233. (b) Bailey, P. J.; Pace, S. Coord. Chem. Rev. 2001, 214, 91. (c) Coles, M. P. Dalton Trans. 2006, 985.

(3) Bourget-Merle, L.; Lappert, M. F.; Severn, J. R. Chem. Rev. 2002, 102,3031 .

Inorganic Chemistry, Vol. 47, No. 24, 200811487 
Chart 1. Skeletons of 1,3-Dicarbonyl (A), 1,5-Diazapentadienyl (B), and 1,3,5-Triazapentadienyl (C) Species

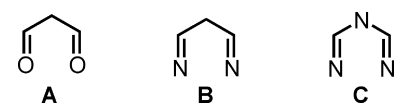

labile metal centers have intrinsic practical applications: e.g., as polymerization catalysts. $^{7-9}$

The trinitrogen analogues of the 1,3-dicarbonyls, i.e. 1,3,5triazapentadienyl (or imidoylamidine) species $(\mathbf{C})$, have been substantially less explored than the relevant $\mathbf{A}$ and $\mathbf{B}$ systems, but they deserve special attention from coordination chemists, as $\mathbf{C}$ ligands offer an additional coordination site at the central nitrogen atom, especially in their anionic form. Moreover, this $\mathrm{N}$ atom takes part in facile acid-base equilibria, ${ }^{10-12}$ thus providing $\mathrm{pH}$ sensing properties to their complexes: e.g., those exhibiting luminescent properties. ${ }^{12}$ Despite the obvious advantages and potential of the 1,3,5triazapentadienyl chelating systems, these species are small in number, since as facile and general synthetic methods for their generation have thus far been rather poorly developed.

Thus, reactions between the preprepared 1,3,5-triazapentadiene and metal sources are rather rare because the ligands, especially those with donor substituents, are highly reactive and therefore many of them are elusive in the free state. Direct metal-ligand reactions have been realized only with stable 1,3,5-triazapentadienes, which bear strong electron acceptor groups at the $\mathrm{C}$ atoms, e.g. fluoroalkyls, and they are $\mathrm{N}$ substituted, e.g. NAr. ${ }^{13-18}$

The unstable 1,3,5-triazapentadienes, which are unsubstituted at the $\mathrm{NH}$ groups and/or contain donor substituents at the carbon atoms $(\mathbf{C})$, are typically prepared by metalmediated reactions such as (i) coupling between amidine(ate)s and nitriles electrophilically activated by ligation to $\mathrm{M}^{\mathrm{II}}$ $\left(\mathrm{Pt}^{\mathrm{II}},{ }^{12,19,20} \mathrm{Pd}^{\mathrm{II}},{ }^{19,21} \mathrm{Ni}^{\mathrm{II}}{ }^{22}\right)$ and $\mathrm{Pt}^{\mathrm{IV}} 20$ centers, (ii) cop-

(4) Brown, E. C.; Bar-Nahum, I.; York, J. T.; Aboelella, N. W.; Tolman, W. B. Inorg. Chem. 2007, 46, 486. Tonzetich, Z. J.; Jiang, A. J.; Schrock, R. R.; Müller, P. Organometallics 2006, 25, 4725. Thompson, J. S.; Bradley, A. Z.; Park, K.-H.; Dobbs, K. D.; Marshall, W. Organometallics 2006, 25, 2712. Gherman, B. F.; Tolman, W. B.; Cramer, C. J. J. Comput. Chem. 2006, 27, 1950.

(5) York, J. T.; Llobet, A.; Cramer, C. J.; Tolman, W. B. J. Am. Chem. Soc. 2007, 129, 7990. Sadique, A. R.; Gregory, E. A.; Brennessel, W. W.; Holland, P. L. J. Am. Chem. Soc. 2007, 129, 8112. Ruspic, C.; Nembenna, S.; Hofmeister, A.; Magull, J.; Harder, S.; Roesky, H. W. J. Am. Chem. Soc. 2006, 128, 15000.

(6) Shimokawa, C.; Teraoka, J.; Tachi, Y.; Itoh, S. I. Inorg. Biochem. 2006, 100, 1118. Aboelella, N. W.; Gherman, B. F.; Hill, L. M. R.; York, J. T.; Holm, N.; Young, V. G.; Cramer, C. J.; Tolman, W. B. J. Am. Chem. Soc. 2006, 128, 3445. Cotton, S. A. Annu. Rep. Prog. Chem., Sect. A: Inorg. Chem. 2005, 101, 208.

(7) Li, Y.; Wang, L.; Gao, H.; Zhu, F.; Wu, Q. Appl. Organomet. Chem. 2006, 20, 436. Smith, K. M. Curr. Org. Chem. 2006, 10, 955.

(8) Li, Y.; Jiang, L.; Wang, L.; Gao, H.; Zhu, F.; Wu, Q. Appl. Organomet. Chem. 2006, 20, 181. Yao, Y.; Zhang, Z.; Peng, H.; Zhang, Y.; Shen, Q.; Lin, J. Inorg. Chem. 2006, 45, 2175.

(9) Fabri, F.; Muterle, R. B.; de Oliveira, W.; Schuchardt, U. Polymer 2006, 47, 4544. Sánchez-Barba, L. F.; Hughes, D. L.; Humphrey, S. M.; Bochmann, M. Organometallics 2006, 25, 1012. Vitanova, D. V.; Hampel, F.; Hultzsch, K. C. J. Organomet. Chem. 2005, 690, 5182.

(10) Kopylovich, M. N.; Pombeiro, A. J. L.; Fischer, A.; Kloo, L.; Kukushkin, V. Yu. Inorg. Chem. 2003, 42, 7239.

(11) Kopylovich, M. N.; Haukka, M.; Kirillov, A. M.; Kukushkin, V. Yu.; Pombeiro, A. J. L. Chem. Eur. J. 2007, 13, 786.

(12) Sarova, G. H.; Bokach, N. A.; Fedorov, A. A.; Berberan-Santos, M. N.; Kukushkin, V. Yu.; Haukka, M.; Fraústo-da-Silva, J. J. R.; Pombeiro, A. J. L. Dalton Trans. 2006, 3798. per- $^{23,24}$ or nickel-mediated ${ }^{25}$ hydrolytic conversion of $1,3,5$ triazine $^{23,25}$ or 1,3,5-tris(2-pyridyl)-2,4,6-triazine, ${ }^{24}$ (iii) hydrolytic conversion of RCN mediated by the dinuclear nickel(II) complex $\left[\mathrm{Ni}_{2}(\mu-\mathrm{OH})_{2}(\text { tpa })_{2}\right]\left(\mathrm{ClO}_{4}\right)_{2}$ (tpa $=$ tris- $(2-$ pyridylmethyl)amine) ${ }^{26}$ or $\mathrm{Ni}(\mathrm{II})$ acetate, ${ }^{27}$ (iv) evaporating a MeOH solution of $\mathrm{NiCl}_{2} \cdot 6 \mathrm{H}_{2} \mathrm{O}$ and acetamidine, ${ }^{28}$ and (v) by oxime-assisted conversion of nitriles at $\mathrm{Pt}^{\mathrm{II}}{ }^{29}$ and $\mathrm{Ni}^{\mathrm{II}} 10,11$ centers.

In the course of our ongoing studies on reactions of metalactivated nitriles, ${ }^{30}$ giving in particular 1,3,5-triazapentadiene complexes, ${ }^{10-12,20}$ we have discovered a novel tailoring reaction between the guanidine $\mathrm{NH}=\mathrm{C}(\mathrm{NHPh})_{2}(\mathrm{DPG})$ and two cis nitriles at the $\mathrm{Pt}^{\mathrm{II}}$ center, leading to platinum(II) 1,3,5triazapentadiene complexes. The developed method, which is based on this reaction, represents a facile route to $(1,3,5-$ triazapentadiene) $\mathrm{Pt}^{\mathrm{II}}$ species with luminescent properties. Details of these results are elaborated in this article.

\section{Results and Discussion}

We have recently reported ${ }^{31}$ on the coupling between tetramethylguanidine $\left(\mathrm{HN}=\mathrm{C}\left(\mathrm{NMe}_{2}\right)_{2}\right)$ and coordinated organonitriles in the platinum(II) complexes cis-/trans$\left[\mathrm{PtCl}_{2}(\mathrm{RCN})_{2}\right](\mathrm{R}=\mathrm{Me}, \mathrm{Et}, \mathrm{Ph})$, which proceeded rapidly

(13) Dias, H. V. R.; Singh, S. Dalton Trans 2006, 1995. Dias, H. V. R.; Singh, S. Inorg. Chem. 2004, 43, 7396. Dias, H. V. R.; Singh, S. Inorg. Chem. 2004, 43, 5786.

(14) Siedle, A. R.; Webb, R. J.; Brostrom, M.; Newmark, R. A.; Behr, F. E.; Young, V. G., Jr. Organometallics 2004, 23, 2281. Siedle, A. R.; Webb, R. J.; Behr, F. E.; Newmark, R. A.; Weil, D. A.; Erickson, K.; Naujok, R.; Brostrom, M.; Mueller, M.; Chou, S.-H.; Young, V. G., Jr. Inorg. Chem. 2003, 42, 932.

(15) Hesse, N.; Fröhlich, R.; Humelnicu, I.; Würthwein, E.-U. Eur. J. Inorg. Chem. 2005, 2189.

(16) Ley, H.; Müller, F. Ber. Dtsch. Chem. Ges 1907, 40, 2950.

(17) Breuer, S. W.; Small, R. W. H. Acta Crystallogr. 1991, C47, 871.

(18) Walther, M.; Wermann, K.; Lutsche, M.; Günther, W.; Görls, H.; Anders, E. J. Org. Chem. 2006, 71, 1399.

(19) Baker, J.; Kilner, M.; Mahmoud, M. M.; Wallwork, S. C. J. Chem. Soc., Dalton Trans. 1989, 837.

(20) Bokach, N. A.; Kuznetsova, T. V.; Simanova, S. A.; Haukka, M.; Pombeiro, A. J. L.; Kukushkin, V. Yu. Inorg. Chem. 2005, 44, 5152.

(21) Guo, J.-P.; Wong, W.-K.; Wong, W.-Y. Eur. J. Inorg. Chem. 2006, 3634.

(22) Guo, J.-P.; Wong, W.-K.; Wong, W.-Y. Eur. J. Inorg. Chem. 2004, 267.

(23) Turnbull, M. M.; Wei, M. Y.; Willett, R. D. J. Coord. Chem. 1995, 35,11 .

(24) Kajiwara, T.; Kamiyama, A. Chem. Commun 2002, 1256. Kajiwara, T.; Kamiyama, A.; Ito, T. Inorg. Chim. Acta 2003, 22, 1789. Kamiyama, A.; Noguchi, T.; Kajiwara, T.; Ito, T. Inorg. Chem. 2002, 41, 507. Lerner, E. I.; Lippard, S. J. J. Am. Chem. Soc. 1976, 98, 5397.

(25) Kajiwara, T.; Ito, T. Eur. J. Inorg. Chem. 2004, 3084.

(26) Kryatov, S. V.; Nazarenko, A. Y.; Smith, M. B.; Rybak-Akimova, E. V. Chem. Commun. 2001, 1174.

(27) Guzei, I. A.; Crozier, K. R.; Nelson, K. J.; Pinkert, J. C.; Schoenfeldt, N. J.; Shepardson, K. E.; McGaff, R. W. Inorg. Chim. Acta 2006, 359, 1169.

(28) Norrestam, R. Acta Crystallogr., Sect. C 1984, 40, 955.

(29) Guedes da Silva, M. F. C.; Ferreira, C. M. P.; Branco, E. M. P. R. P.; Fraústo da Silva, J. J. R.; Pombeiro, A. J. L.; Michelin, R. A.; Belluco, U.; Bertani, R.; Mozzon, M.; Bombieri, G.; Benetollo, F.; Kukushkin, V. Yu. Inorg. Chim. Acta 1997, 265, 267 (Topical Volume on Platinum Chemistry)

(30) For reviews see: Kukushkin, V. Yu.; Pombeiro, A. J. L. Chem. Rev. 2002, 102, 1771. Pombeiro, A. J. L.; Kukushkin, V. Yu. Reactions of Coordinated Nitriles. In Comprehensive Coordination Chemistry, 2nd ed.; Elsevier: Amsterdam, 2004; Vol. 1, Chapter 1.34, pp 639-660.

(31) Gushchin, P. V.; Bokach, N. A.; Luzyanin, K. V.; Nazarov, A. A.; Haukka, M.; Kukushkin, V. Yu. Inorg. Chem. 2007, 46, 1684. 
Scheme 1. Tailoring Reaction in the Temperature Range (A) from 20 to $40{ }^{\circ} \mathrm{C}\left(\mathrm{R}=\mathrm{Me}(\mathbf{1}), \mathrm{Et}(\mathbf{2}), \mathrm{CH}_{2} \mathrm{Ph}(\mathbf{3}), \mathrm{Ph}(\mathbf{4})\right)$ and (B) from -20 to $4{ }^{\circ} \mathrm{C}\left(\mathrm{R}=\mathrm{Et}(\mathbf{5}), \mathrm{CH}_{2} \mathrm{Ph}(\mathbf{6})\right)$

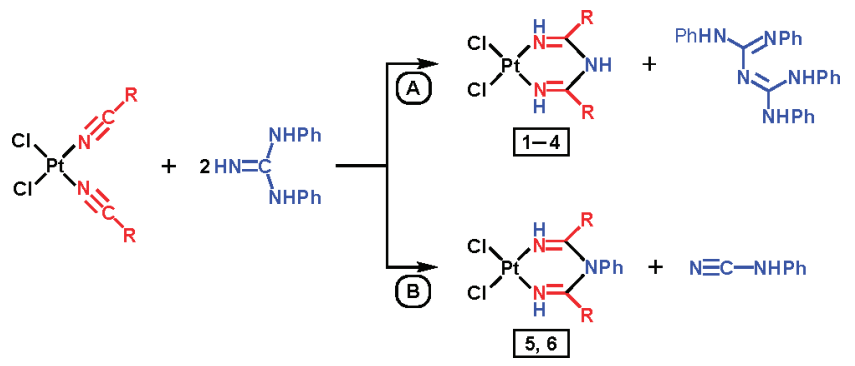

under mild conditions and afforded diimino compounds containing two $\mathrm{N}$-bound monodentate 1,3-diaza-1,3-diene ligands, $\left[\mathrm{PtCl}_{2}\left\{\mathrm{NH}=\mathrm{C}(\mathrm{R}) \mathrm{N}=\mathrm{C}\left(\mathrm{NMe}_{2}\right)_{2}\right\}_{2}\right]$; this reaction was the first observation of metal-mediated nucleophilic addition of a guanidine to ligated nitrile.

As a continuation of the project focused on the study of metal-mediated nitrile-guanidine interplay, we attempted the reaction between another guanidine, e.g. $N, N^{\prime}$-diphenylguanidine $\left(\mathrm{NH}=\mathrm{C}(\mathrm{NHPh})_{2}\right)$ and the $\mathrm{Pt}^{\mathrm{II}}$ precursors and found that the process with $\mathrm{NH}=\mathrm{C}(\mathrm{NHPh})_{2}$ was strongly different from that with $\mathrm{HN}=\mathrm{C}\left(\mathrm{NMe}_{2}\right)_{2}$. Indeed, at the cis- $\mathrm{Pt}^{\mathrm{II}}$ centers a novel tailoring process is realized instead of the coupling, although at the trans- $\mathrm{Pt}^{\mathrm{II}}$ centers the interaction follows the expected route; all of these processes will be considered below in separate sections.

Nitrile-Guanidine Coupling at the cis- $(\mathrm{RCN})_{2} \mathbf{P t}^{\mathrm{II}}$ Center. The tailoring reaction of the two adjacent nitrile ligands in cis- $\left[\mathrm{PtCl}_{2}(\mathrm{RCN})_{2}\right]\left(\mathrm{R}=\mathrm{Me}, \mathrm{Et}, \mathrm{CH}_{2} \mathrm{Ph}, \mathrm{Ph}\right)$ upon interaction with $\mathrm{NH}=\mathrm{C}(\mathrm{NHPh})_{2}$ in a 1:2 molar ratio proceeds in the corresponding $\mathrm{RCN}$ (for $\mathrm{R}=\mathrm{Me}, \mathrm{Et}$ ) and in $\mathrm{CH}_{2} \mathrm{Cl}_{2}$ (for $\mathrm{R}=\mathrm{Ph}, \mathrm{CH}_{2} \mathrm{Ph}$ ) at $20-25^{\circ} \mathrm{C}$ for $24 \mathrm{~h}$ or at $40{ }^{\circ} \mathrm{C}$ for $2 \mathrm{~h}$ and gives a 50-60\% yield of Pt 1,3,5-triazapentadiene complexes 1-4 (Scheme 1, route A).

In all cases, the complexes were separated by filtration and the filtrates contain, as was verified by TLC, more than 10 as yet unidentified products. In addition to $\mathbf{1 - 4}$, another major product formed in the reaction is, most likely, diphenylcarbodiimide $\mathrm{PhN}=\mathrm{C}=\mathrm{NPh}$, but this heterocumulene is highly reactive and couples with $\mathrm{HN}=\mathrm{C}(\mathrm{NHPh})_{2}$ to give the biguanidine $\mathrm{PhN}=\mathrm{C}(\mathrm{NHPh}) \mathrm{N}=\mathrm{C}(\mathrm{NHPh})_{2}$, which was detected by $\mathrm{ESI}^{+}$-MS $\left(\mathrm{m} / z, 406[\mathrm{M}+\mathrm{H}]^{+}\right)($Scheme 1 , route $\mathrm{A}$ ); similar reactions between carbodiimides and various $\mathrm{N}$-donor nucleophiles are well-known from the literature. ${ }^{31,32}$ It is worth noticing that (i) we did not observe the higher molecular weight products, which may originate from further bis(guanidine) and (nitrile) $\mathrm{Pt}^{\mathrm{II}}$ coupling, in accord with our previous findings $\mathrm{s}^{33}$ and (ii) N,N-chelating

(32) Zhang, W.-X.; Nishiura, M.; Hou, Z. Chem. Eur. J. 2007, 13, 4037. Ma, L.; Zhang, J.; Cai, R.; Chen, Z.; Zhou, X. Dalton Trans. 2007, 25, 2718. Guiducci, A. E.; Boyd, C. L.; Mountford, P. Organometallics 2006, 25, 1167. Ding, M.-W.; Yang, S.-J.; Zhu, J. Synthesis 2004, 1, 75. Bell, S. A.; Meyer, T. Y.; Geib, S. J. J. Am. Chem. Soc. 2002, 124, 10698. Molina, P.; Alajarin, M.; Perez de Vega, M. J.; Lopez, A. Heterocycles 1989, 29, 1607. Ibrahim, I. T.; Williams, A. J. Chem. Soc., Perkin Trans. 2 1982, 11, 1455. Kurzer, F.; Douraghi-Zadeh, K. J. Chem. Soc. 1965, 3912.

(33) Bokach, N. A.; Kukushkin, V. Yu.; Haukka, M.; Fraústo da Silva, J. J. R.; Pombeiro, A. J. L. Inorg. Chem. 2003, 42, 3602.
Scheme 2

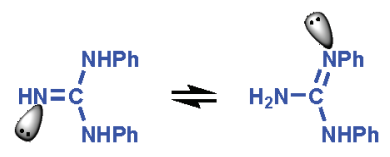

properties of the bis(guanidine) explain the insufficient selectivity of the tailoring: $\mathrm{ESI}^{+}$-MS monitoring of the reaction mixture allows the detection of the bisguanidine chelation products (see the Experimental Section).

The reaction in $\mathrm{CH}_{2} \mathrm{Cl}_{2}$ proceeds differently at lower temperatures. When the reaction between $c i s-\left[\mathrm{PtCl}_{2}(\mathrm{RCN})_{2}\right]$ $\left(\mathrm{R}=\mathrm{Et}, \mathrm{CH}_{2} \mathrm{Ph}\right)$ and $\mathrm{DPG}$ in a 1:2 molar ratio starts at -20 ${ }^{\circ} \mathrm{C}$ followed by heating to $4{ }^{\circ} \mathrm{C}$ and keeping the mixture under this temperature for 1 day, the $\mathrm{NH}$ tailoring (compounds $\mathbf{2}$ and $\mathbf{3}$; isolated yields are $35 \%$ and $26 \%$, respectively) (Scheme 1, route A) is accompanied by the NPh tailoring, giving 5 and $\mathbf{6}$ in ca. $4 \%$ and $25 \%$ yields, respectively (Scheme 1, route B). Precipitates were weighed, fully dissolved in DMSO- $d_{6}$, and analyzed by ${ }^{1} \mathrm{H}$ NMR. The molar ratios 2:5 and 3:6 obtained by NMR integration are ca. 8:1 and ca. 1:1, respectively. Yields of $\mathbf{2}$ and $\mathbf{5}$ and of $\mathbf{3}$ and 6 were calculated on the basis of these ${ }^{1} \mathrm{H}$ NMR data. Another product of the route B (Scheme 1) is the known ${ }^{34}$ phenylcyanamide $\left(\mathrm{ESI}^{-}-\mathrm{MS}, \mathrm{m} / z 117[\mathrm{M}-\mathrm{H}]^{-}\right)$. In two other cases (i.e., $\mathrm{R}=\mathrm{Ph}, \mathrm{Me}$ ), we were unable to isolate the NPh-tailoring products: first, the reaction of cis$\left[\mathrm{PtCl}_{2}(\mathrm{PhCN})_{2}\right]$ with DPG at $-20{ }^{\circ} \mathrm{C}$ in $\mathrm{CH}_{2} \mathrm{Cl}_{2}$ is not selective, and in addition, all products which were formed exhibit solubility too high to allow separation by fractional recrystallization; second, the very poor solubility of cis$\left[\mathrm{PtCl}_{2}(\mathrm{MeCN})_{2}\right]$ prevented us from pursuing further studies.

It is worth noting that complex $\mathbf{6}$ could also be obtained at $20-25{ }^{\circ} \mathrm{C}$ in $\mathrm{CH}_{2} \mathrm{Cl}_{2}$ by the reaction of cis- $\left[\mathrm{PtCl}_{2}-\right.$ $\left.\left(\mathrm{PhCH}_{2} \mathrm{CN}\right)_{2}\right]$ with DPG in a 1:4 molar ratio; however, the yield of solid product $\mathbf{6}(9 \%)$ is small and the filtrate contains a broad spectrum of as yet unidentified products. It was also found that $\mathbf{6}$ is not formed at all in the reaction between cis- $\left[\mathrm{PtCl}_{2}\left(\mathrm{PhCH}_{2} \mathrm{CN}\right)_{2}\right]$ and the guanidine in a 1:4 molar ratio at $20-25{ }^{\circ} \mathrm{C}$ in $\mathrm{MeNO}_{2}$; in the latter case the only poorly soluble product is complex $\mathbf{3}$ (yield 33\%). Consequently, one might assume that the selectivity of the tailoring reaction, i.e. $\mathrm{NH}$ vs. $\mathrm{NPh}$ tailoring, of the two adjacent $\mathrm{RCN}$ nitrile ligands in cis-[ $\left.\mathrm{PtCl}_{2}(\mathrm{RCN})_{2}\right]$ depends on the solvent polarity. This viewpoint can be rationalized by the solvent-dependent tautomeric equilibrium of $\mathrm{DPG}^{35}$ (Scheme 2; the left form predominates in polar solvents) and, consequently, by involvement of two different nucleophilic centers ( $\mathrm{NH}$ vs $\mathrm{NPh}$ ) in the initial step of the reaction.

A plausible mechanism (Scheme 3) of the tailoring involves nucleophilic attack of the $\mathrm{Pt}^{\mathrm{II}}$-activated nitrile by either the $\mathrm{NH}$ (route $\mathrm{C}$ ) or $\mathrm{NPh}$ (route G) center and formation of the eight-membered chelates formed via routes

(34) Crutchley, R. J. Compr. Coord. Chem. II 2004, 1, 117. Crutchley, R. J. Coord. Chem. Rev. 2001, 125, 219-221.

(35) Bureiko, S. F.; Koll, A.; Przeslawska, M. J. Struct. Chem. 2002, 43, 412. Bocharov, V. N.; Bureiko, S. F.; Koll, A.; Rospenk, M. J. Struct. Chem. 1999, 39, 502. Koll, A.; Rospenk, M.; Bureiko, S. F.; Bocharov, V. N. J. Phys. Org. Chem. 1996, 9, 487. Clement, B.; Kaempchen, T. Chem. Ber. 1986, 119, 1101. 


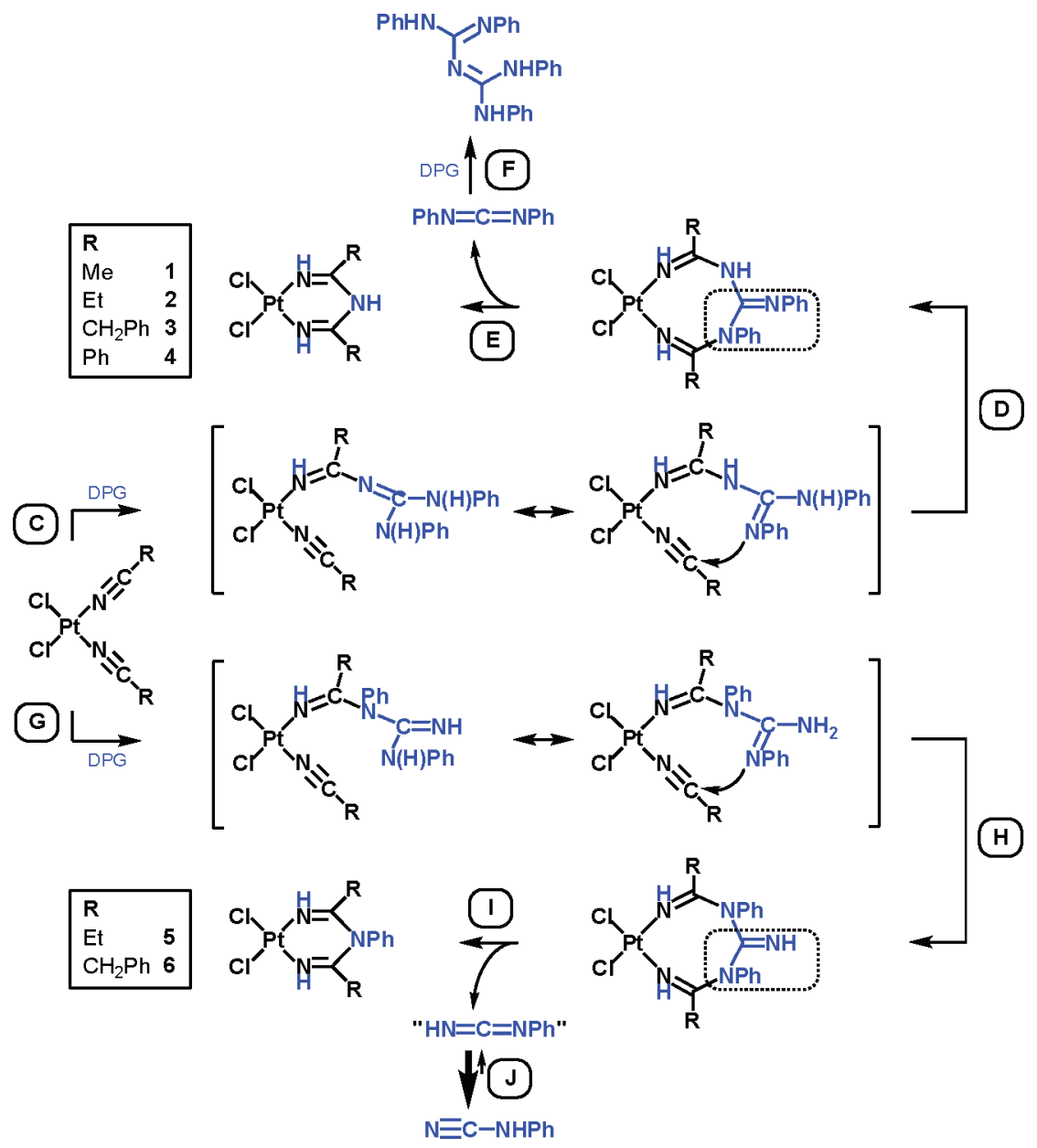

$\mathrm{C} / \mathrm{D}$ and $\mathrm{G} / \mathrm{H}$. Although these chelates should be unstable, they could be isolated by us for the complexes cis- $\left[\mathrm{PtCl}_{2}-\right.$ $(\mathrm{RCN})_{2}$ ] bearing highly conjugated RCN species, and these data will be published separately. ${ }^{36}$ Extruding the carbodiimide and narrowing the chelate ring (routes $\mathrm{E}$ and I) gives the products of $\mathrm{NH}$ and $\mathrm{NPh}$ tailoring, respectively. The fate of the carbodiimide is different and depends on its nature. Thus, $\mathrm{PhN}=\mathrm{C}=\mathrm{NPh}$ couples with excess DPG (route $\mathrm{F}$ ), yielding the bis(guanidine), while $\mathrm{HN}=\mathrm{C}=\mathrm{NPh}$ rapidly tautomerizes ${ }^{37}$ to the nitrile $\mathrm{NCN}(\mathrm{H}) \mathrm{Ph}$ (route $\mathrm{J}$ ), which is unreactive toward DPG.

Thus, we can see that the guanidine $\mathrm{NH}=\mathrm{C}(\mathrm{NHPh})_{2}$ reacts with cis-( $\mathrm{RCN})_{2} \mathrm{Pt}^{\mathrm{II}}$ centers and serves as the $\mathrm{NH}_{2} \mathrm{R}^{1}$-tailoring reagent $\left(\mathrm{R}^{1}=\mathrm{H}, \mathrm{Ph}\right)$ for the two adjacent nitrile ligands in cis- $\left[\mathrm{PtCl}_{2}(\mathrm{RCN})_{2}\right]\left(\mathrm{R}=\mathrm{Me}, \mathrm{Et}, \mathrm{CH}_{2} \mathrm{Ph}, \mathrm{Ph}\right)$ at $20-25{ }^{\circ} \mathrm{C}$ $\left(\mathrm{R}^{1}=\mathrm{H}\right)$ or at $-20{ }^{\circ} \mathrm{C}\left(\mathrm{R}^{1}=\mathrm{Ph}\right)$.

Different Reactivity Modes of the cis-(EtCN $)_{2} \mathrm{Pt}^{\mathrm{II}}$ Moiety and DPG or $\mathbf{N H}_{3}$. Being interested in the amplification of the tailoring reaction to other $(\mathrm{RCN})_{2} \mathrm{Pt}^{\mathrm{II}}$ complexes, we decided to apply the reaction with DPG for the $N, N, N^{\prime}, N^{\prime}-$

(36) Gushchin, P. V.; Bokach, N. A.; Haukka, M.; Kukushkin, V. Yu. Unpublished work.

(37) Boyer, J. H.; Frints, P. J. A. J. Heterocycl. Chem. 1970, 7, 71; Chem. Abstr. 1970, 72, 90378. Lempert, K.; Puskas, J.; Bekassy, S. Period. Polytech., Chem. Eng. 1968, 12, 123; Chem. Abstr. 1969, 70, 11239. tetramethylethylenediamine (tmeda) complex cis-[Pt(tmeda)$\left.(\mathrm{EtCN})_{2}\right]\left[\mathrm{SO}_{3} \mathrm{CF}_{3}\right]_{2}\left(\mathbf{8} \cdot(\mathrm{OTf})_{2}\right.$; prepared from $\mathbf{7}^{38}$ via route $\mathrm{K}$, Scheme 4). It is important that the tmeda chelation provides exclusive cis arrangement of the nitrile species, thus

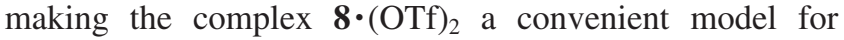
studying the tailoring reaction with DPG as well as for comparison of reactivity modes between the $c i s-(\mathrm{EtCN})_{2} \mathrm{Pt}^{\mathrm{II}}$ moiety and DPG vs $\mathrm{NH}_{3}$.

When a dichloromethane solution of $\mathbf{8} \cdot(\mathrm{OTf})_{2}$ was treated with an excess of gaseous ammonia at $20-25{ }^{\circ} \mathrm{C}$ for $6 \mathrm{~h}$ (Scheme 4, route L), the formation of the platinum(II) bis(amidine) complex cis-[Pt(tmeda) $\left.\left\{\mathrm{NH}=\mathrm{C}\left(\mathrm{NH}_{2}\right) \mathrm{Et}\right\}_{2}\right]-$ $\left[\mathrm{SO}_{3} \mathrm{CF}_{3}\right]_{2}\left(\boldsymbol{9} \cdot(\mathrm{OTf})_{2}\right)$ was observed and it was isolated in $85 \%$ yield; the ammination proceeds in accord with previous observations. ${ }^{39-45}{ }^{1} \mathrm{H}$ NMR monitoring proved the absence of the tailoring product $\left[\mathrm{Pt}(\mathrm{tmeda})\{\mathrm{NH}=\mathrm{C}(\mathrm{Et})\}_{2} \mathrm{NH}\right]-$ $\left[\mathrm{SO}_{3} \mathrm{CF}_{3}\right]_{2}\left(\mathbf{1 0} \cdot(\mathrm{OTf})_{2}\right)$ in the reaction mixture. In contrast,

(38) Monti, E.; Gariboldi, M.; Maiocchi, A.; Marengo, E.; Cassino, C.; Gabano, E.; Osella, D. J. Med. Chem. 2005, 48, 857.

(39) Kukushkin, V. Yu.; Aleksandrova, E. A.; Kukushkin, Yu. N. Zh. Obshch. Khim. 1995, 65, 1937; Chem. Abstr. 1996, 125, 24936.

(40) Kukushkin, Yu. N.; Aleksandrova, E. A.; Pakhomova, T. B. Zh. Obshch. Khim. 1994, 64, 151; Chem. Abstr. 1994, 122, 121719.

(41) Kukushkin, Yu. N.; Aleksandrova, E. A.; Pakhomova, T. B.; Vlasova, R. A. Zh. Obshch. Khim. 1994, 64, 705; Chem. Abstr. 1995, 121, 147636.

(42) Longato, B.; Bandoli, G.; Mucci, A.; Schenetti, L. Eur. J. Inorg. Chem. 2001, 3021. 


\section{Scheme 4}
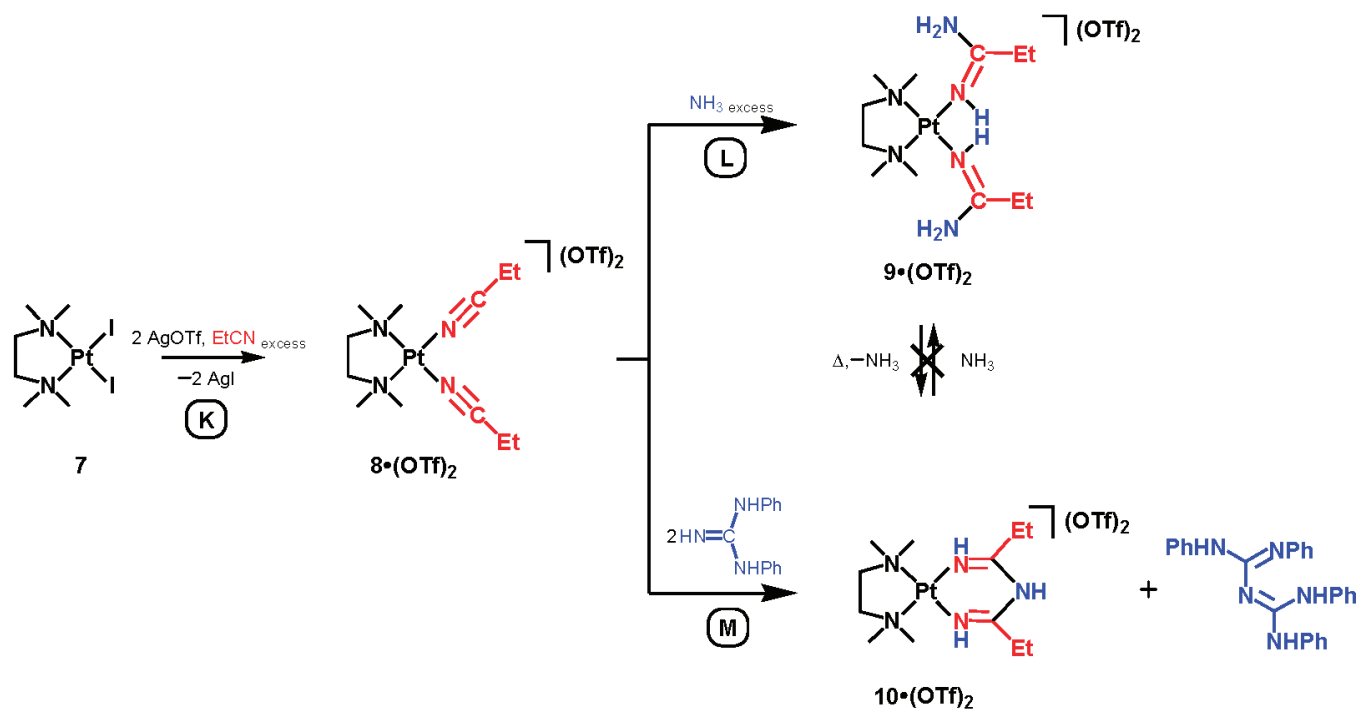

the reaction of $\mathbf{8} \cdot(\mathrm{OTf})_{2}$ and DPG performed under similar conditions (Scheme 4, route $\mathrm{M}$ ) led to the (1,3,5-triazapentadiene) $\mathrm{Pt}^{\mathrm{II}}$ complex 10・(OTf $)_{2}$, derived from the tailoring reaction, and no $9 \cdot(\mathrm{OTf})_{2}$ was detected in the reaction mixture.

Moreover, in separate experiments it was established that (i) the chelate $\mathbf{1 0} \cdot(\mathrm{OTf})_{2}$ did not react with ammonia in a methanolic solution $\left(6 \mathrm{~h}, 20-25{ }^{\circ} \mathrm{C}\right)$ to give $9 \cdot(\mathrm{OTf})_{2}$ and (ii) the bis(amidine) complex $9 \cdot(\mathrm{OTf})_{2}$ did not convert to 10. $(\mathrm{OTf})_{2}$ upon heating either in solution $\left(24 \mathrm{~h}, 100{ }^{\circ} \mathrm{C}\right.$, $\mathrm{MeNO}_{2}$ ) or in the solid state (gradual decomposition from ca. $115{ }^{\circ} \mathrm{C}$ on TG; see Figure $\mathrm{S} 1$ in the Supporting Information). These observations (Scheme 4 , routes $\mathrm{L}$ and $\mathrm{M}$ ) indicate the unique character of the reaction and point out that the role of DPG is more complicated and does not come from the donation of ammonia in the novel tailoring reaction, thus additionally supporting the plausible mechanism depicted in Scheme 3.

Nitrile-Guanidine Coupling at the trans- $(\mathrm{RCN})_{2} \mathrm{Pt}^{\mathrm{II}}$ Center. The complex trans-[ $\left.\mathrm{PtCl}_{2}(\mathrm{MeCN})_{2}\right]$ exhibits poor solubility in most noncoordinating solvents, and the reaction between DPG and the more soluble trans- $\left[\mathrm{PtCl}_{2}(\mathrm{RCN})_{2}\right](\mathrm{R}$ $\left.=\mathrm{Et}, \mathrm{CH}_{2} \mathrm{Ph}, \mathrm{Ph}\right)$ was studied. Treatment of trans[ $\left.\mathrm{PtCl}_{2}(\mathrm{RCN})_{2}\right]\left(\mathrm{R}=\mathrm{Et}, \mathrm{CH}_{2} \mathrm{Ph}, \mathrm{Ph}\right)$ with 2 equiv of $\mathrm{DPG}$ in EtCN $(\mathrm{R}=\mathrm{Et})$ or $\mathrm{CH}_{2} \mathrm{Cl}_{2}\left(\mathrm{R}=\mathrm{CH}_{2} \mathrm{Ph}, \mathrm{Ph}\right)$ solutions at $20-25{ }^{\circ} \mathrm{C}$ for $15-24 \mathrm{~h}$ resulted in formation of $[\mathrm{PtCl}\{\mathrm{NH}=$ $\mathrm{C}(\mathrm{R}) \mathrm{NC}(\mathrm{NHPh})=N \mathrm{Ph}\}(\mathrm{RCN})](\mathbf{1 1}-\mathbf{1 3})$, which were isolated in 45,26 , and $20 \%$ yields, respectively, by taking the reaction mixture to dryness, followed by washing of the solid residue with $\mathrm{MeOH}(\mathrm{R}=\mathrm{Et})$ or after column chromatography on $\mathrm{SiO}_{2}\left(\mathrm{R}=\mathrm{CH}_{2} \mathrm{Ph}, \mathrm{Ph}\right)$; in all three cases solutions also

(43) Belluco, U.; Benetollo, F.; Bertani, R.; Bombieri, G.; Michelin, R. A.; Mozzon, M.; Tonon, O.; Pombeiro, A. J. L.; Guedes da Silva, F. C. Inorg. Chim. Acta 2002, 334, 437.

(44) Belluco, U.; Benetollo, F.; Bertani, R.; Bombieri, G.; Michelin, R. A.; Mozzon, M.; Pombeiro, A. J. L.; Guedes da Silva, F. C. Inorg. Chim. Acta 2002, 330, 225

(45) Natile, G.; Intini, F. P.; Bertani, R.; Michelin, R. A.; Mozzon, M.; Sbovata, S. M.; Venzo, A.; Seraglia, R. J. Organomet. Chem. 2005, 690, 2121.
Scheme 5
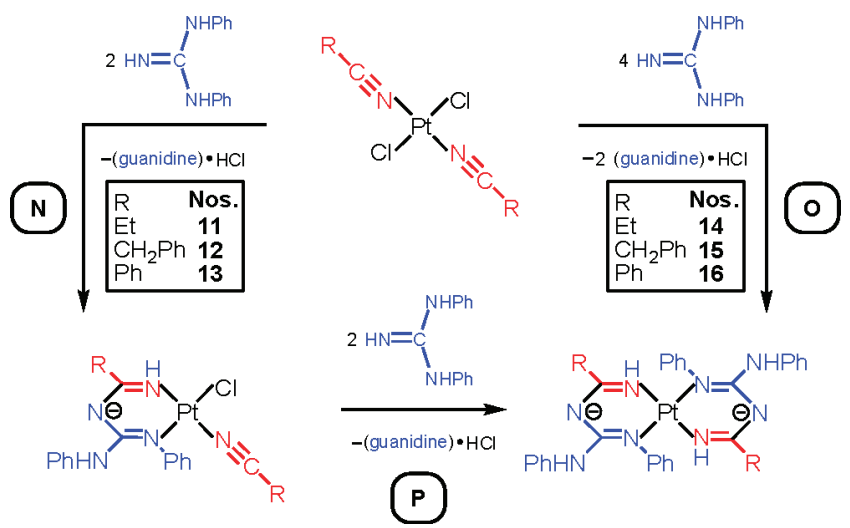

contain a broad mixture of as yet unidentified compounds. Complexes 11-13 formed as products of the nucleophilic addition of DPG to the nitrile carbon atom, followed by ring closure of the formed 1,3,5-triazapentadiene ligand (Scheme 5 , route $\mathrm{N})$. It is noteworthy that when trans- $\left[\mathrm{PtCl}_{2}(\mathrm{RCN})_{2}\right]$ $\left(\mathrm{R}=\mathrm{Et}, \mathrm{CH}_{2} \mathrm{Ph}, \mathrm{Ph}\right)$ reacts with 2 equiv of DPG at room temperature, complexes 14-16 (see below) are not formed.

A further increase in the amount of DPG from 2 to 3 equiv decreases the yield of $\mathbf{1 1 - 1 3}$ to ca. $\mathbf{1 0 \%}$. The yield of $\mathbf{1 1}$ is higher if the solvent is the corresponding nitrile rather than $\mathrm{CH}_{2} \mathrm{Cl}_{2}$ or $\mathrm{CHCl}_{3}$ (45\% when the reaction is carried out in EtCN vs $20 \%$ in $\mathrm{CH}_{2} \mathrm{Cl}_{2}$ ). Unfortunately, the preparation of 12 and 13 in $\mathrm{PhCH}_{2} \mathrm{CN}$ or $\mathrm{PhCN}$, respectively, is not practical due to the low volatility of these solvents and difficulties in crystallizing the final products.

When trans- $\left[\mathrm{PtCl}_{2}(\mathrm{RCN})_{2}\right]\left(\mathrm{R}=\mathrm{Et}, \mathrm{CH}_{2} \mathrm{Ph}, \mathrm{Ph}\right)$ react in the corresponding nitrile RCN with 4 equiv of DPG for a prolonged reaction time (1-2 days) at $75^{\circ} \mathrm{C}$ (Scheme 5, route O) or 11-13 are treated with 2 equiv more of DPG at the same temperature (Scheme 5, route $\mathrm{P}$ ), complexes containing two bidentate 1,3,5-triazapentadiene ligands, i.e. $[\mathrm{Pt}\{\mathrm{NH}=$ $\left.\mathrm{C}(\mathrm{R}) \mathrm{NC}(\mathrm{NHPh})=\mathrm{NPh}\}_{2}\right](\mathbf{1 4}-\mathbf{1 6})$, are formed and they are isolated in $63-73 \%$ yields. Thus, the reaction of DPG and the trans- $(\mathrm{RCN})_{2} \mathrm{Pt}$ complexes follows the expected path 


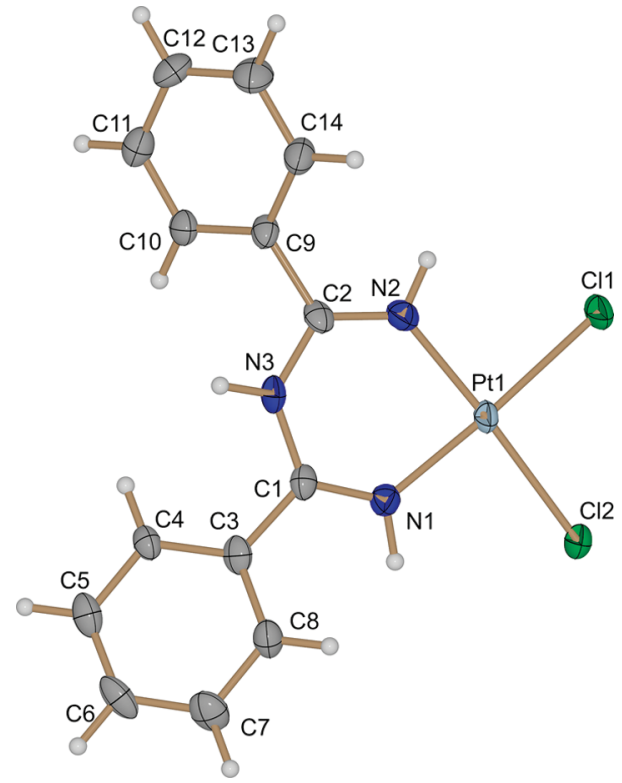

Figure 1. Thermal ellipsoid view of complex 4 with the atomic numbering scheme. Thermal ellipsoids are drawn at the $50 \%$ probability level.

previously established by us for the metal-mediated nitrileamidine coupling. ${ }^{20}$

Characterization of (1,3,5-triazapentadiene) $\mathrm{Pt}^{\mathrm{II}} \mathrm{Com}$ plexes. The formulation of complexes $\mathbf{1 - 4}, \mathbf{9} \cdot(\mathrm{OTf})_{2}$, 10· $(\mathrm{OTf})_{2}$, and 11-16 was supported by satisfactory $\mathrm{C}, \mathrm{H}$, and $\mathrm{N}$ elemental analyses, in agreement with $\mathrm{FAB}^{+}(\mathbf{1}-\mathbf{3}$, 9•(OTf $\left.)_{2}, \mathbf{1 1 - 1 6}\right), \mathrm{ESI}^{+}-\mathrm{MS}\left(\mathbf{5}, \mathbf{6}, \mathbf{8} \cdot(\mathrm{OTf})_{2}, \mathbf{1 0} \cdot(\mathrm{OTf})_{2}\right)$, and $\mathrm{ESI}^{-}$-MS (1-6) data. In the IR spectra, (1,3,5-triazapentadiene/ato $) \mathrm{Pt}^{\mathrm{II}}(\mathbf{1}-\mathbf{4}), \quad \mathbf{1 0} \cdot(\mathrm{OTf})_{2}, \mathbf{1 1 - 1 6}$, and also the (amidine) ${ }_{2} \mathrm{Pt}^{\mathrm{II}}$ complex $\mathbf{9} \cdot(\mathrm{OTf})_{2}$ display strong $v(\mathrm{C}=\mathrm{N})$ or $v(\mathrm{C}=\mathrm{N}$ and/or $\mathrm{C}=\mathrm{C})$ bands in the range 1672-1442 $\mathrm{cm}^{-1}$. The structures of $1,2,4,11,13$, and 14 and picrates of complexes $\mathbf{9}^{2+}$ and $\mathbf{1 0}^{2+}$ were determined by single-crystal $\mathrm{X}$-ray diffraction.

(A) Complexes 1-4. Comparison of the IR spectra of 1-4 with those of the starting materials indicates the absence of the $\mathrm{C} \equiv \mathrm{N}$ stretching vibrations and the presence of strong $v(\mathrm{C}=\mathrm{N})$ bands in the range $1672-1539 \mathrm{~cm}^{-1}$ and $\mathrm{N}-\mathrm{H}$ stretching vibrations, which emerge at higher frequencies (3396-3043 $\left.\mathrm{cm}^{-1}\right)$. A characteristic feature of the ${ }^{1} \mathrm{H}$ NMR spectra of $\mathbf{1 - 4}$ is the availability of two singlets with 1:2 intensities from the $\mathrm{NH}$ protons at 11.28-10.65 and 10.22-9.45 ppm, respectively. The position of the signals at such a low field gives indirect evidence that the $\mathrm{NH}$ proton is involved in hydrogen bonding in solution. ${ }^{46}$ The most downfield signal in the region of $11.28-10.65 \mathrm{ppm}$ corresponds to the proton at the central $\mathrm{N}$ atom.

The structures of $\mathbf{1}, \mathbf{2}$, and $\mathbf{4}$ were determined by X-ray single-crystal diffraction (Figure 1 and Figures S2 and S3 in the Supporting Information), and it was observed that they

(46) Makarycheva-Mikhailova, A. V.; Haukka, M.; Bokach, N. A.; Garnovskii, D. A.; Galanski, M.; Keppler, B. K.; Pombeiro, A. J. L.; Kukushkin, V. Yu. New J. Chem. 2002, 26, 1085. Kukushkin, V. Yu.; Pakhomova, T. B.; Bokach, N. A.; Wagner, G.; Kuznetsov, M. L.; Galanski, M.; Pombeiro, A. J. L. Inorg. Chem. 2000, 39, 216. Kukushkin, V. Yu.; Pakhomova, T. B.; Kukushkin, Yu. N.; Herrmann, R.; Wagner, G.; Pombeiro, A. J. L. Inorg. Chem. 1998, 37, 6511. all have square-planar geometry. In 1, 2, and 4, atoms forming the metallacycles lie in one plane with the rms deviations $0.009(3)(\mathbf{1}), 0.059(3)$ (2), and 0.064(5) ̊ (4). The $\mathrm{CN}$ bonds in the metallacycles of $\mathbf{1}, \mathbf{2}$, and $\mathbf{4}$ have a low degree of delocalization. The bond lengths $\mathrm{N}(1)-\mathrm{C}(1)$, $\mathrm{N}(2)-\mathrm{C}(2)$ in $\mathbf{1}, \mathbf{2}$, and $\mathbf{4}$ are 1.287(4), 1.285(4) $\AA, 1.287(5)$, 1.281(5) $\AA$, and 1.289(7), 1.286(7), 1.297(7), 1.298(7), 1.281(7), 1.291(7) A, respectively (Table 1). These values are closer to the $\mathrm{C}=\mathrm{N}$ double-bond value and comparable with the corresponding $\mathrm{C}=\mathrm{N}$ double bonds of the bis-cationic (1,3,5-triazapentadiene/ato) $\mathrm{Ni}^{\mathrm{II}}$ complex $[\mathrm{Ni}\{\mathrm{NH}=\mathrm{C}(\mathrm{R}) \mathrm{NHC}$ $\left.(\mathrm{R})=\mathrm{NH}\}_{2}\right]^{2+}(1.282(3)-1.294(3) \AA) .{ }^{10}$ The bond lengths $\mathrm{N}(3)-\mathrm{C}(1), \mathrm{N}(3)-\mathrm{C}(2)$ in $\mathbf{1}, \mathbf{2}$, and $\mathbf{4}$ are 1.363(4), 1.374(4) $\AA$, 1.368(4), 1.379(4) $\AA$, and 1.391(7), 1.366(7), 1.378(7), 1.374(7), 1.386(7), 1.376(8) А, respectively. These values are closer to the $\mathrm{C}-\mathrm{N}$ single-bond value and comparable with the corresponding $\mathrm{C}-\mathrm{N}$ single-bond values of the biscationic (1,3,5-triazapentadiene/ato) $\mathrm{Ni}^{\mathrm{II}}$ complex $[\mathrm{Ni}\{\mathrm{NH}=$ $\left.\mathrm{C}(\mathrm{R}) \mathrm{NHC}(\mathrm{R})=\mathrm{NH}\}_{2}\right]^{2+}(1.357(4)-1.374(4) \AA) .{ }^{10}$ In 4, the adjacent molecules are linked by weak $(\mathrm{NH} \cdot \cdot \mathrm{Cl})$ interactions (Figure S5 and Table S1 in the Supporting Information).

(B) Complexes $9 \cdot\left(\mathrm{OTf}_{2}\right.$ and 10 $\left(\mathrm{OTf}_{2}\right.$. In the IR spectra of 9•(OTf $)_{2}$ and 10 $(\mathrm{OTf})_{2}$, the $\mathrm{Pt}^{\mathrm{II}}$-bound amidine and 1,3,5triazapentadiene ligands exhibit medium-to-strong bands at 3439-3242 $\mathrm{cm}^{-1}$, which can be attributed to the $\mathrm{N}-\mathrm{H}$ stretching vibrations, and display no bands in the region specific to $v(\mathrm{C} \equiv \mathrm{N})$ stretches. The IR spectrum of $\mathbf{9} \cdot(\mathrm{OTf})_{2}$ shows $\mathrm{C}=\mathrm{N}$ absorption bands in the range between 1659 and $1616 \mathrm{~cm}^{-1}$ characteristic of amidine ligands, while for 10 $(\mathrm{OTf})_{2}$, the $v(\mathrm{C}=\mathrm{N})$ peaks of the 1,3,5-triazapentadiene ligand appear as two strong bands at 1610 and $1547 \mathrm{~cm}^{-1}$. The latter values are lower than those for the (amidine) ${ }_{2} \mathrm{Pt}^{\mathrm{II}}$ complex 9•(OTf $)_{2}$, and this fact can be rationalized by a conjugation (although of low degree; see later discussion on the X-ray structures) within the 1,3,5-triazapentadienyl chelating system.

The amidine resonances of $\mathbf{9 \cdot}(\mathrm{OTf})_{2}$ are observed in the ${ }^{1} \mathrm{H}$ NMR spectrum as broad singlets in a 1:1:1 ratio at 6.68 ppm for the imino $(\mathrm{HN}=\mathrm{C})$ protons and at 7.07 and 7.43 ppm for the amido $\left(\mathrm{H}_{2} \mathrm{NC}\right)$ protons; we believe these sets of signals are related to the existence of a few conformational forms in solution. In the ${ }^{1} \mathrm{H}$ NMR spectrum of $\mathbf{1 0} \cdot(\mathrm{OTf})_{2}$, $\mathrm{NH}$ resonances moved to low field and emerged at 10.94 ppm for the proton at the central $\mathrm{N}$ atom and at $9.22 \mathrm{ppm}$ for the imino protons $(\mathrm{HN}=\mathrm{C})$ in a $1: 2$ ratio. In the ${ }^{13} \mathrm{C}\left\{{ }^{1} \mathrm{H}\right\}$ $\mathrm{NMR}$ spectra, the carbons from the $\mathrm{N}=\mathrm{C}-\mathrm{N}$ moiety were detected at ca. $174 \mathrm{ppm}$ for $\mathbf{9 \cdot ( O T f})_{2}$ and at ca. $164 \mathrm{ppm}$ for $\mathbf{1 0} \cdot(\mathrm{OTf})_{2}$.

Complexes $\mathbf{9}^{2+}$ and $\mathbf{1 0}^{2+}$ were isolated as the picrates, and these two salts give crystals suitable for X-ray diffraction studies (Figure 2, Table 2). The $\mathrm{Pt}-\mathrm{N}_{\text {tmeda }}$ bonds in $\mathbf{9}^{2+}$ (2.059(6), 2.074(5) $\AA$ ) and $\mathbf{1 0}^{2+}(2.071(3), 2.078(3) \AA)$ and the $\mathrm{Pt}-\mathrm{N}_{\text {imine }}$ bonds in $\mathbf{9}^{2+}(1.997(5), 1.999(5) \AA)$ and $\mathbf{1 0}^{2+}$ (1.987(3), 1.991(3) ^) agree well with each other and with those found in $\left[\mathrm{Pt}\left\{\mathrm{NH}=\mathrm{C}\left(\mathrm{NH}_{2}\right) \mathrm{NMe}_{2}\right\}\right.$ (dien) $]\left[\mathrm{SO}_{3} \mathrm{CF}_{3}\right]_{2}$ $($ dien $=$ diethylenetriamine $)(2.036(6)-2.049(6) \AA$ for 

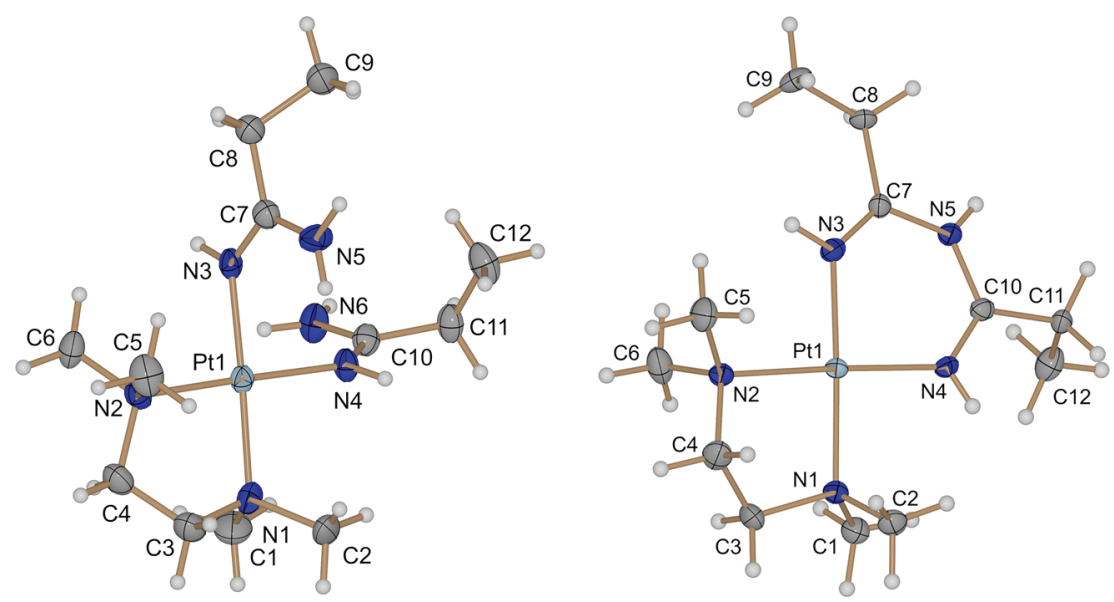

Figure 2. Thermal ellipsoid views of complexes $\mathbf{9}^{2+}$ (left) and $\mathbf{1 0}^{2+}$ (right) with the atomic numbering scheme. Thermal ellipsoids are drawn at the $50 \%$ probability level. The picrate anions are omitted for simplicity.

Table 1. Selected Bond Lengths $(\AA)$ and Angles (deg) for 1, 2, and 4

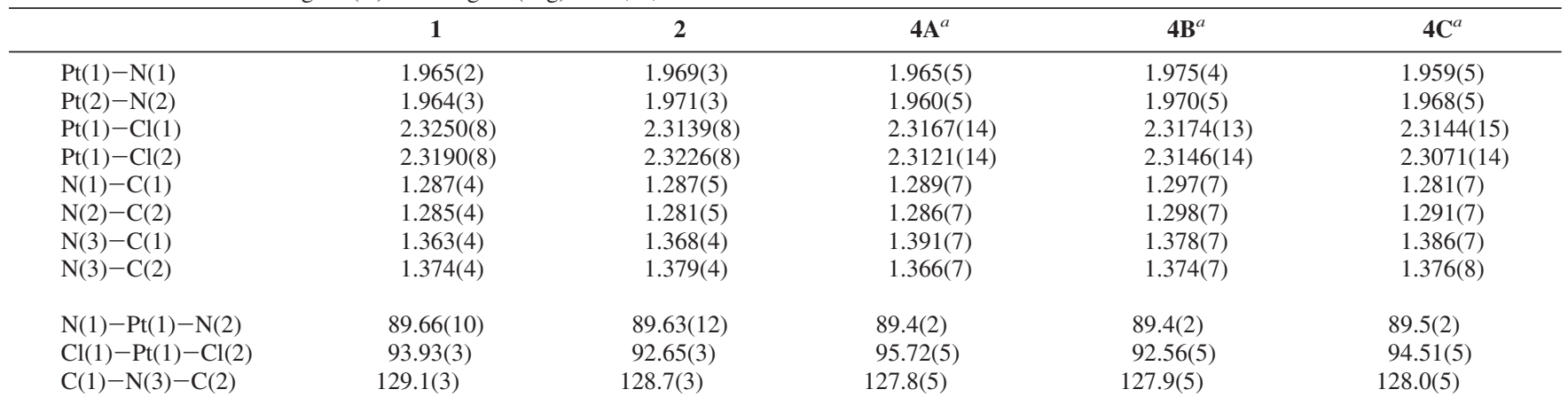

${ }^{a}$ The asymmetric unit of $\mathbf{4}$ contains three independent molecules.

Table 2. Selected Bond Lengths $(\AA)$ and Angles (deg) for $\mathbf{9}^{2+}$ and $\mathbf{1 0}^{2+}$

\begin{tabular}{lcc}
\hline & $\mathbf{9}^{2+}$ & $\mathbf{1 0}^{2+}$ \\
\hline $\mathrm{Pt}(1)-\mathrm{N}(1)$ & $2.059(6)$ & $2.071(3)$ \\
$\mathrm{Pt}(1)-\mathrm{N}(2)$ & $2.074(5)$ & $2.078(3)$ \\
$\mathrm{Pt}(1)-\mathrm{N}(3)$ & $1.999(5)$ & $1.991(3)$ \\
$\mathrm{Pt}(1)-\mathrm{N}(4)$ & $1.997(5)$ & $1.987(3)$ \\
$\mathrm{N}(1)-\mathrm{C}(3)$ & $1.494(9)$ & $1.505(5)$ \\
$\mathrm{N}(2)-\mathrm{C}(4)$ & $1.494(8)$ & $1.495(5)$ \\
$\mathrm{N}(3)-\mathrm{C}(7)$ & $1.299(8)$ & $1.282(5)$ \\
$\mathrm{N}(5)-\mathrm{C}(7)$ & $1.326(8)$ & $1.364(5)$ \\
$\mathrm{C}(3)-\mathrm{C}(4)$ & $1.491(10)$ & $1.493(6)$ \\
$\mathrm{N}(1)-\mathrm{Pt}(1)-\mathrm{N}(2)$ & & \\
$\mathrm{N}(3)-\mathrm{Pt}(1)-\mathrm{N}(4)$ & $85.6(2)$ & $85.31(12)$ \\
$\mathrm{N}(3)-\mathrm{C}(7)-\mathrm{N}(5)$ & $88.3(2)$ & $88.08(12)$ \\
& $120.9(6)$ & $122.0(3)$
\end{tabular}

$\mathrm{Pt}-\mathrm{N}_{\text {dien }}$ and 1.997(6), 2.018(7) $\AA$ for $\left.\mathrm{Pt}-\mathrm{N}_{\text {imine }}\right) .{ }^{47}$ The $\mathrm{C}=\mathrm{N}$ bond lengths in (amidine) ${ }_{2} \mathrm{Pt}^{\mathrm{II}}$ (tmeda) (1.288(8) and 1.299(8) $\AA)$ and (1,3,5-triazapentadiene) $\mathrm{Pt}^{\mathrm{II}}($ tmeda) $(1.279(5)$ and $1.282(5) \AA$ ) and the $\mathrm{C}-\mathrm{N}$ bond lengths (1.326(8) and

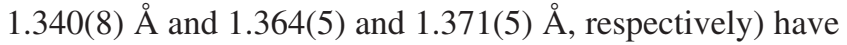
values typical for the (amidine) ${ }_{2} \mathrm{Pt}^{\mathrm{II}}$ complexes ${ }^{43,44}$ and for the (1,3,5-triazapentadiene) $\mathrm{Pt}^{\mathrm{II}}$ complexes, listed above, and correspond, within $3 \sigma$, with each other. Therefore, the bond lengths are statistically equivalent within the two classes of ligands, and differences between complexes $\mathbf{9}^{2+}$ and $\mathbf{1 0}^{2+}$ are observed only in their spectra.

(47) Fairlie, D. P.; Jackson, W. G.; Skelton, B. W.; Wen, H.; White, A. H.; Wickramasinghe, W. A.; Woon, T. C.; Taube, H. Inorg. Chem. 1997, $36,1020$.
(C) Complexes 11-16. The IR spectra of these compounds display strong $v(\mathrm{C}=\mathrm{N}$ and/or $\mathrm{C}=\mathrm{C})$ bands at 1636-1442 $\mathrm{cm}^{-1}$ and $\mathrm{N}-\mathrm{H}$ stretching vibrations in the range of $3422-3338 \mathrm{~cm}^{-1}$. These ranges agree well with values of $v(\mathrm{C}=\mathrm{N}$ and/or $\mathrm{C}=\mathrm{C})\left(1632-1430 \mathrm{~cm}^{-1}\right)$ and $\nu(\mathrm{N}-\mathrm{H})$ (3395-3282 $\left.\mathrm{cm}^{-1}\right)$ bands for the (1,3,5-triazapentadiene/ ato) $\mathrm{Pt}^{\mathrm{II}}$ complexes $[\mathrm{PtCl}(\mathrm{NCR})\{N \mathrm{H}=\mathrm{C}(\mathrm{R}) \mathrm{NC}(\mathrm{Ph}) N(\mathrm{Ph})\}]$ and $\left[\mathrm{Pt}\{N \mathrm{H}=\mathrm{C}(\mathrm{R}) \mathrm{NC}(\mathrm{Ph}) N(\mathrm{Ph})\}_{2}\right]\left(\mathrm{Et}, \mathrm{CH}_{2} \mathrm{Ph}, \mathrm{Ph}\right){ }^{20}$ The weak $\mathrm{C} \equiv \mathrm{N}$ stretching vibrations are present in the IR spectra for compounds 11-13 but not in those for complexes 14-16. This can be rationalized by the fact that $\mathbf{1 4 - 1 6}$ are products of the nucleophilic addition of DPG to both nitriles RCN of trans- $\left[\mathrm{PtCl}_{2}(\mathrm{RCN})_{2}\right]\left(\mathrm{R}=\mathrm{Et}, \mathrm{CH}_{2} \mathrm{Ph}, \mathrm{Ph}\right)$, while $\mathbf{1 1}-\mathbf{1 3}$ are formed in the reaction incorporating one ligand $\mathrm{RCN}$ of trans- $\left[\mathrm{PtCl}_{2}(\mathrm{RCN})_{2}\right]\left(\mathrm{R}=\mathrm{Et}, \mathrm{CH}_{2} \mathrm{Ph}, \mathrm{Ph}\right)$ with $\mathrm{DPG}$. The characteristic feature of ${ }^{1} \mathrm{H}$ NMR spectra of the $(1,3,5$ triazapentadiene/ato) $\mathrm{Pt}^{\mathrm{II}}$ complexes $\mathbf{1 1 - 1 6}$ is the presence of two singlets due to the $\mathrm{NH}$ protons in the range of 6.50-4.84 ppm.

The structures of $\mathbf{1 1}, \mathbf{1 3}$, and $\mathbf{1 4}$ were determined by single-crystal X-ray diffraction (Figures 3 and 4, Table 3, and Figure $\mathrm{S} 4$ in the Supporting Information). They all have square-planar geometry. In 11, the disordered coordinated nitrile is bent $\left(\mathrm{N}(4)-\mathrm{C}(3)-\mathrm{C}(4 \mathrm{~A})=168.4(6)^{\circ}\right.$ and $\mathrm{N}(4)-$ $\left.\mathrm{C}(4)-\mathrm{C}(\mathrm{C} 4 \mathrm{~B})=154.9(6)^{\circ}\right)$, probably because of the steric repulsion from the aromatic ring of the chelated ligand, while in $\mathbf{1 3}$ the nitrile fragment is linear $(\mathrm{N}(4)-\mathrm{C}(3)-\mathrm{C}(4)=$ $\left.179.0(7)^{\circ}\right)$. The bond lengths of $\mathrm{N}(3)-\mathrm{C}(2)$ in $\mathbf{1 1}$ and 


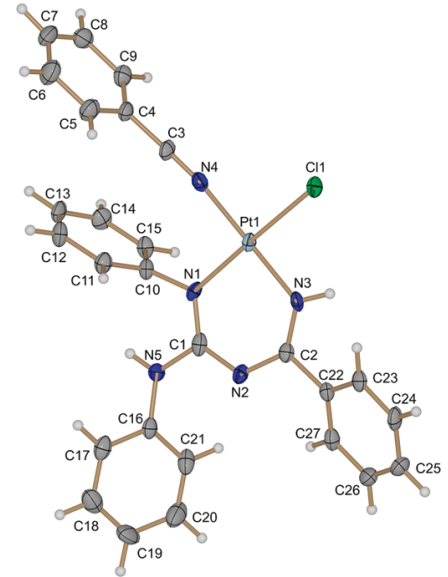

Figure 3. Thermal ellipsoid view of complex 13 with the atomic numbering scheme. Thermal ellipsoids are drawn at the $50 \%$ probability level.

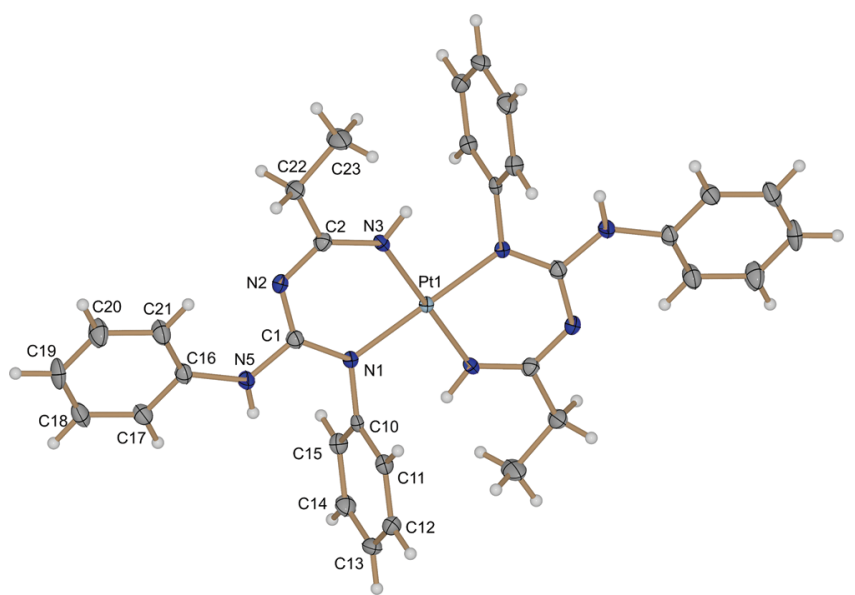

Figure 4. Thermal ellipsoid view of complex 14 with the atomic numbering scheme. Thermal ellipsoids are drawn at the $50 \%$ probability level.

Table 3. Selected Bond Lengths $(\AA)$ and Angles (deg) for 11, 13, and 14

\begin{tabular}{lccc}
\hline & $\mathbf{1 1}$ & $\mathbf{1 3}$ & $\mathbf{1 4}$ \\
\hline $\mathrm{Pt}(1)-\mathrm{N}(1)$ & $2.017(2)$ & $2.001(5)$ & $2.039(2)$ \\
$\mathrm{Pt}(1)-\mathrm{N}(3)$ & $1.952(3)$ & $1.941(5)$ & $1.990(2)$ \\
$\mathrm{Pt}(1)-\mathrm{N}(4)$ & $2.001(3)$ & $1.979(5)$ & \\
$\mathrm{Pt}(1)-\mathrm{Cl}(1)$ & $2.3112(8)$ & $2.3169(15)$ & \\
$\mathrm{N}(1)-\mathrm{C}(1)$ & $1.330(4)$ & $1.354(8)$ & $1.339(3)$ \\
$\mathrm{N}(2)-\mathrm{C}(1)$ & $1.346(4)$ & $1.345(8)$ & $1.332(3)$ \\
$\mathrm{N}(2)-\mathrm{C}(2)$ & $1.333(4)$ & $1.352(8)$ & $1.344(3)$ \\
$\mathrm{N}(3)-\mathrm{C}(2)$ & $1.313(4)$ & $1.330(8)$ & $1.306(3)$ \\
$\mathrm{N}(5)-\mathrm{C}(1)$ & $1.370(4)$ & $1.372(8)$ & $1.381(3)$ \\
$\mathrm{N}(5)-\mathrm{C}(16)$ & $1.414(4)$ & $1.422(8)$ & $1.414(3)$ \\
$\mathrm{N}(4)-\mathrm{C}(3)$ & $1.115(5)$ & $1.154(8)$ & \\
$\mathrm{C}(3)-\mathrm{C}(4)$ & & $1.434(8)$ & \\
$\mathrm{C}(3)-\mathrm{C}(4 \mathrm{~A})^{a}$ & $1.489(7)$ & & \\
$\mathrm{C}(3)-\mathrm{C}(4 \mathrm{~B})^{a}$ & $1.605(12)$ & & \\
& & & \\
$\mathrm{N}(1)-\mathrm{Pt}(1)-\mathrm{N}(3)$ & $88.76(10)$ & $89.6(2)$ & $87.23(8)$ \\
$\mathrm{Cl}(1)-\mathrm{Pt}(1)-\mathrm{N}(4)$ & $89.14(8)$ & $90.26(15)$ & $122.8(2)$ \\
$\mathrm{C}(1)-\mathrm{Pt}(1)-\mathrm{C}(2)$ & $123.3(3)$ & $121.9(5)$ & \\
$\mathrm{C}(1)-\mathrm{N}(5)-\mathrm{C}(16)$ & $128.9(2)$ & $127.9(5)$ & \\
$\mathrm{Pt}(1)-\mathrm{N}(4)-\mathrm{C}(3)$ & $174.8(3)$ & $172.9(5)$ & \\
${ }^{a} \mathrm{In} \mathbf{1 1}, \mathrm{C}(4)$ is disordered over two sites. &
\end{tabular}

$\mathrm{N}(3)-\mathrm{C}(2)$ in 14 (1.313(4) and 1.306(3) $\AA$, respectively) have values typical for the corresponding $\mathrm{N}=\mathrm{C}$ bonds in both $\mathrm{Pt}^{\mathrm{II}}$ and $\mathrm{Ni}^{\mathrm{II}} 1,3,5$-triazapentadiene/ato complexes ${ }^{10,20}$ and, within $3 \sigma$, the $\mathrm{N}=\mathrm{C}$ bond in compounds with the

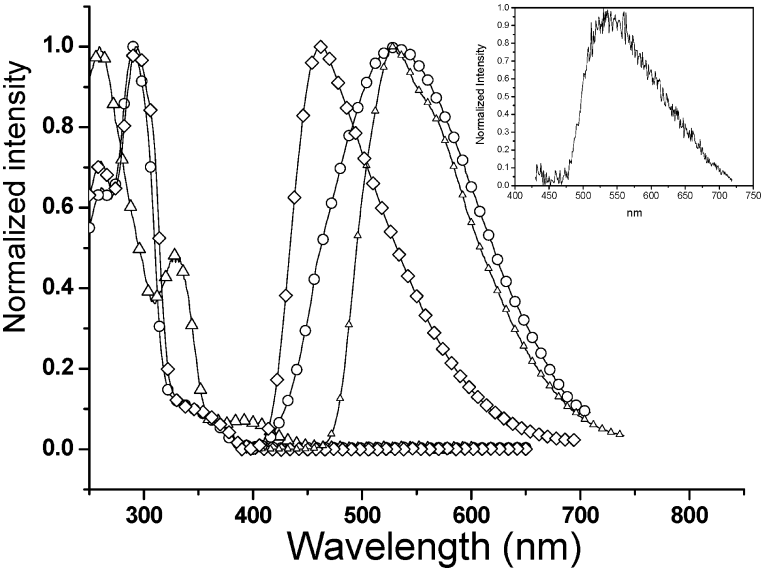

Figure 5. Absorption spectra in $\mathrm{CH}_{2} \mathrm{Cl}_{2}$ and the normalized solid-state emission spectra of $14(\bigcirc), 15(\square)$, and $16(\triangle)$. Inset: emission spectrum of 16 in $\mathrm{CH}_{2} \mathrm{Cl}_{2}$. The excitation wavelength is set at $350 \mathrm{~nm}$. All measurements were performed at $25^{\circ} \mathrm{C}$.

$\mathrm{C}_{\mathrm{Ar}}-\mathrm{C}=\mathrm{N}-\mathrm{C}$ moiety ${ }^{48}$ (mean value $1.279(8) \AA$ ). The bond lengths $\mathrm{N}(2)-\mathrm{C}(2)$ and $\mathrm{N}(2)-\mathrm{C}(1)$ in $\mathbf{1 1}$ (1.333(4) and $1.346(4) \AA$, respectively) and in 14 (1.344(3) and 1.332(3) $\AA$, respectively) have values closer to the corresponding $\mathrm{N}-\mathrm{C}$ bonds in both (1,3,5-triazapentadiene/ato $) \mathrm{M}\left(\mathrm{M}=\mathrm{Pt}^{\mathrm{II}}, \mathrm{Ni}^{\mathrm{II}}\right)$ complexes. ${ }^{10,20}$ The bond lengths $\mathrm{N}(1)-\mathrm{C}(1)$ in $\mathbf{1 1}(1.330$ (4) $\AA$ ) and in $\mathbf{1 4}(1.339(3) \AA)$ are longer than the corresponding $\mathrm{N}=\mathrm{C}$ bond lengths in both (1,3,5-triazapentadiene/ato) $\mathrm{M}(\mathrm{M}$ $\left.=\mathrm{Pt}^{\mathrm{II}}, \mathrm{Ni}^{\mathrm{II}}\right)$ complexes,${ }^{10,20}$ which can be related to the influence of the NHPh group. However, all values still remain typical, within $3 \sigma$, for such types of 1,3,5-triazapentadiene/ ato metallacycles. The $\mathrm{N}=\mathrm{C}$ and $\mathrm{N}-\mathrm{C}$ bond lengths in the metallacycles $\mathbf{1 1}$ and 14, in contrast to the case for $(1,3,5$ triazapentadiene/ato $) \mathrm{M}\left(\mathrm{M}=\mathrm{Pt}^{\mathrm{II}}, \mathrm{Ni}^{\mathrm{II}}\right),{ }^{10,20}$ exhibit a greater degree of delocalization in the ring. The distinct distribution of double and single $\mathrm{CN}$ bonds in the metallacycle $\mathbf{1 3}$ is vague (the bond lengths $\mathrm{N}(3)-\mathrm{C}(2), \mathrm{N}(2)-\mathrm{C}(2), \mathrm{N}(2)-\mathrm{C}(1)$, and $\mathrm{N}(1)-\mathrm{C}(1)$ are $1.330(8), 1.352(8), 1.345(8)$, and 1.354(8) $\AA$, respectively); it has a greater degree of the delocalization in comparison to $\mathbf{1 1}$ and $\mathbf{1 4}$ and a significantly higher degree of delocalization as compared with $\mathrm{Pt}^{\mathrm{II}}$ and $\mathrm{Ni}^{\mathrm{II}} 1,3,5$ triazapentadiene/ato complexes. ${ }^{10,20}$ In $\mathbf{1 1}, \mathbf{1 3}$, and $\mathbf{1 4}$ the atoms of the metallacycles lie in one plane with rms deviations 0.094(3) (11), 0.061(5) (13), and 0.143(2) ̊ (14).

Photophysical Data for 14-16 and Theoretical Approaches for Their Interpretation. Focus of this section is mainly on complexes $\mathbf{1 4 - 1 6}$, due to their unique structures and great luminescence intensity in the solid state (vide infra). The absorption and luminescence spectra have been recorded for 14-16 in $\mathrm{CH}_{2} \mathrm{Cl}_{2}$ and in the solid state. The associated spectra are depicted in Figure 5, and pertinent data are summarized in Table 4 . In general, the high-energy absorption bands at $<300 \mathrm{~nm}$ for 14-16 can be reasonably assigned to the 1,3,5-triazapentadiene $\pi \pi^{*}$ transition. The next lower energy band with a shoulder at $\sim 350 \mathrm{~nm}(390 \mathrm{~nm}$ for 16) is assigned to the spin-allowed metal-to-ligand charge transfer ( ${ }^{1}$ MLCT) transition, due to its relatively lower absorptivity. Supplementary support of these assignments is also provided

(48) Allen, F. H.; Kennard, O.; Watson, D. G.; Brammer, L.; Orpen, A. G.; Taylor, R. J. Chem. Soc., Perkin Trans. 2 1987, S1. 
Table 4. Photophysical Properties of 14-16

\begin{tabular}{cccccc}
\hline & $\lambda_{\mathrm{abs}}(\mathrm{nm})^{a}$ & $\lambda_{\text {emission }}, \mathrm{nm}^{b}$ & $\Phi_{\mathrm{f}}{ }^{b}$ & $\tau_{\mathrm{obs}}(\mu \mathrm{s})^{b}$ & $\tau_{\mathrm{r}}(\mu \mathrm{s})^{b}$ \\
\hline $\mathbf{1 4}$ & 295,353 & 530 & 0.39 & 2.62 & $6.72^{b}$ \\
$\mathbf{1 5}$ & 290,351 & 460 & 0.61 & 3.69 & $6.04^{b}$ \\
$\mathbf{1 6}$ & 315,380 & 530 & 0.74 & 0.82 & $1.10^{b}$ \\
& & 535 & $0.007^{c}$ & $0.01^{c}$ & $1.71^{c}$
\end{tabular}

${ }^{a}$ The absorption spectrum was acquired in $\mathrm{CH}_{2} \mathrm{Cl}_{2} \cdot{ }^{b}$ Measurements were perfomed in the solid state. $\tau_{\mathrm{obs}}$ and $\tau_{\mathrm{r}}$ denote the observed and radiative decay times, respectively. ${ }^{c}$ Data were recorded in degassed $\mathrm{CH}_{2} \mathrm{Cl}_{2}$ solution using three freeze-pump-thaw cycles.

by the computational approaches (vide infra). We unfortunately could not resolve any emission for complexes $\mathbf{1 4}$ and 15 in degassed $\mathrm{CH}_{2} \mathrm{Cl}_{2}$ solutions at room temperature, while a weak emission (quantum yield $\Phi_{\mathrm{f}} \approx 7 \times 10^{-3}$ ) was resolved with a peak wavelength at $\sim 535 \mathrm{~nm}$ (see inset of Figure 5). Taking into account the sensitivity of the current detection system, the emission yield for $\mathbf{1 4}$ and 15, if there is any, is concluded to be less than $10^{-5}$. Such an observation is similar to the case for many $\mathrm{Pt}^{\mathrm{II}}$ complexes, which are emissive in the solid state, whereas they are nonemissive in fluid solutions at room temperature. ${ }^{49}$ The title Pt complexes are in a square-planar configuration and possess an empty $\mathrm{d}$ orbital perpendicular to the plane. The empty orbital is subject to coordination by electron donors in the solvent, resulting in a dominant radiationless transition. The quenching processes associated with e.g. solvent collision and/or large amplitude motions can be drastically reduced in the form of a solid film. Supporting evidence is provided by the strong emission acquired in the solid state for the studied complexes, with $\Phi_{\mathrm{f}}$ being measured to be $0.39,0.61$, and 0.74 for 14-16, respectively (see Figure 5 and Table 4). Knowing that $\Phi_{\mathrm{f}} \times \tau_{\mathrm{r}}=\tau_{\mathrm{obs}}$, where $\tau_{\mathrm{obs}}$ and $\tau_{\mathrm{r}}$ denote the measured and radiative lifetimes, respectively, $\tau_{\mathrm{r}}$ for 14-16 can thus be calculated and are given in Table 4. Clearly, the deduced radiative lifetime of microseconds for all 14-16 confirms the origin of emission from the triplet manifold: i.e., phosphorescence ${ }^{50,51}$ Furthermore, the short radiative lifetime, in combination with the lack of vibronic progression in emission spectra, manifests the $\mathrm{T}_{1}-\mathrm{S}_{0}$ transition to be MLCT mixed, in part, with $\pi \pi^{*}$ character. For complex 16, the emission spectrum in view of peak wavelength and spectral features in $\mathrm{CH}_{2} \mathrm{Cl}_{2}$ is similar to that in the solid film. Since $\mathbf{1 6}$ should exist in a well-dispersed, monomeric form in $\mathrm{CH}_{2} \mathrm{Cl}_{2}$, it is thus reasonable to conclude negligible intermolecular $\mathrm{Pt}-\mathrm{Pt}$ nonbonding interactions for $\mathbf{1 6}$ in the solid film. Knowing such interactions frequently take place in $\mathrm{Pt}^{\mathrm{II}}$ complexes, ${ }^{52}$ the negligible $\mathrm{Pt}^{\mathrm{II}}$ packing interaction in solid films can possibly be rationalized by the overall nonplanar structure, avoiding significant intermolecular interaction.

(49) Kui, S. C. F.; Chui, S. S. Y.; Che, C. M.; Zhu, N. J. Am. Chem. Soc. 2006, $128,8297$.

(50) Chang, S.-Y.; Kavitha, J.; Hung, J.-Y.; Chi, Y.; Cheng, Y.-M.; Li, E. Y.; Chou, P.-T.; Lee, G.-H.; Carty, A. J. Inorg. Chem. 2007, 46, 7064.

(51) Scaffidi-Domianello, Y. Yu.; Nazarov, A. A.; Haukka, M.; Galanski, M.; Keppler, B. K.; Schneider, J.; Du, P.; Eisenberg, R.; Kukushkin, V. Yu. Inorg. Chem. 2007, 46, 4469.

(52) Chang, S.-Y.; Kavitha, J.; Li, S.-W.; Hsu, C.-S.; Chi, Y.; Yeh, Y.-S.; Chou, P.-T.; Lee, G.-H.; Carty, A. J.; Tao, Y.-T.; Chien, C.-H. Inorg. Chem. 2006, 45, 137.
To gain more insight into the above photophysical behavior, the electronic transition properties calculations of 14-16 were performed using density functional theory method (DFT). With the use of the TD-B3LYP method incorporating the obtained geometries from the structural optimization calculations, the vertical (i.e., Franck-Condon) excitation energy from the ground state to the lowest lying electronic excited state in both singlet and triplet manifolds was calculated. The TDDFT results are summarized in Figure 6. Clearly, the calculated $S_{1}$ and $T_{1}$ energy levels for the title complexes are qualitatively consistent with the $0-0$ onset of the absorption $\left(\mathrm{S}_{1}\right)$ and phosphorescence $\left(\mathrm{T}_{1}\right)$ spectra. Thus, the theoretical level adopted here should be suitable for studying the photophysical properties of these complexes in a qualitative manner. As shown in Figure 6, the transitions to $S_{1}$ and $T_{1}$ are mainly attributed to the HOMO $\rightarrow$ LUMO transition for complexes $\mathbf{1 4}$ and $\mathbf{1 6}$, while the excitation, in part, also involves the $\mathrm{HOMO} \rightarrow \mathrm{LUMO}+1$ transition for complex 15. The frontier orbitals, HOMO, and LUMO for 14-16 are also depicted in Figure 6. Evidently, the $\mathrm{HOMO} \rightarrow$ LUMO transition for all the complexes involves metal to ligand charge transfer (MLCT) and part of the ligand $\pi \pi^{*}$ character. For complexes $\mathbf{1 4}$ and 15, the transitions also incorporate certain degrees of the $\mathrm{dd}^{*}$ transition. Knowing that a dd* transition normally causes weakness of the metal-ligand bonding strength, the results may partially account for the nonemissive properties of complexes 14 and 15 in $\mathrm{CH}_{2} \mathrm{Cl}_{2}$. Further support is given by complex 16. In sharp contrast to complexes $\mathbf{1 4}$ and $\mathbf{1 5}$, the lowest lying state of complex 16 involves negligible dd* transition and hence 16 exhibits a relatively higher quantum yield of 0.007 in $\mathrm{CH}_{2} \mathrm{Cl}_{2}$. It is also noteworthy that a similar dd* transition may not cause drastic radiationless quenching in the solid state due to the confinement of the lattice energy.

\section{Final Remarks}

The results from this work can be summarized into three perspectives. First, the tailoring reaction between two cisligated RCN species represents a novel reactivity mode, which has never been reported at any metal center. Although this synthetic transformation was demonstrated only for nitriles at $\mathrm{Pt}^{\mathrm{II}}$ centers, we anticipate amplifying this type of reaction to RCN ligands at other metal centers and extending the application to, for example various homoleptic nitrile hard or soft metal complexes. ${ }^{53}$ Second, the tailoring reaction constitutes a facile route to the trinitrogen analogues of the 1,3-dicarbonyls, i.e., Pt 1,3,5-triazapentadienyl complexes. Despite increasing interest in the latter systems, relevant reports are rare, mainly because the synthetic methods so far are rather poorly developed. Third, bis(1,3,5-triazapentadiene) $\mathrm{Pt}^{\mathrm{II}}$ complexes such as $\mathbf{1 4 - 1 6}$ are found to exhibit strong luminescence in the solid state, raising the future possibility that these systems may be useful for sensing or

(53) Davies, J. A.; Hockensmith, C. M.; Kukushkin, V. Yu.; Kukushkin, Yu. N. Synthetic Coordination Chemistry: Principles and Practice; World Scientific: Singapore, 1996; pp 95-156. 


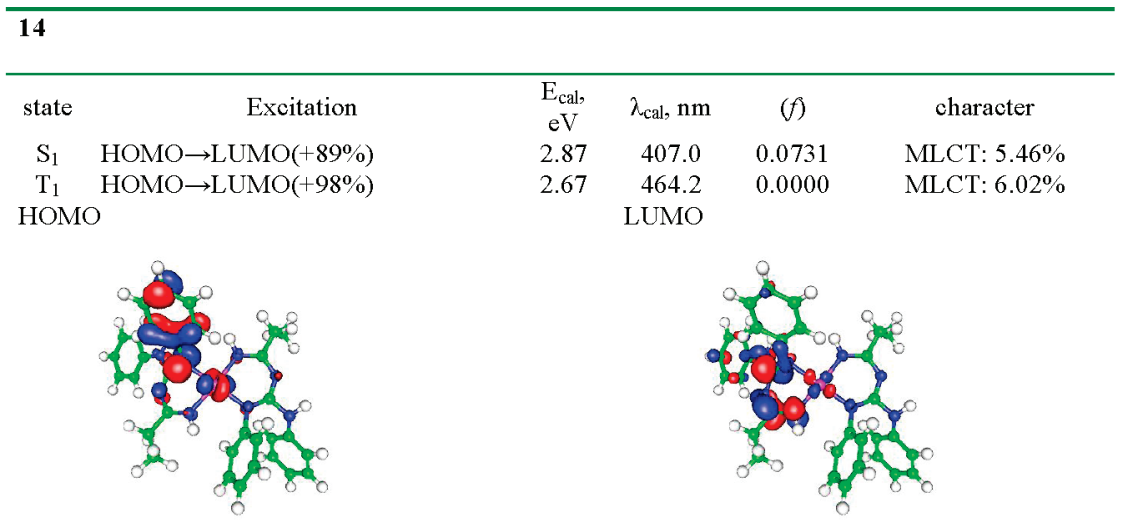

15
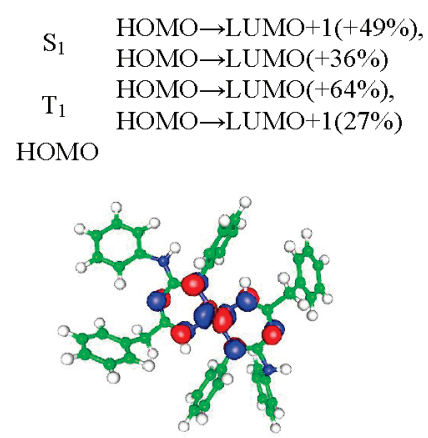

$\mathrm{LUMO}+1$

$\begin{array}{rrrr}3.25 & 381.3 & 0.0009 & \text { MLCT: } 24.77 \% \\ 3.02 & 409.9 & 0.0000 & \text { MLCT: } 27.76 \% \\ & \text { LUMO } & & \end{array}$

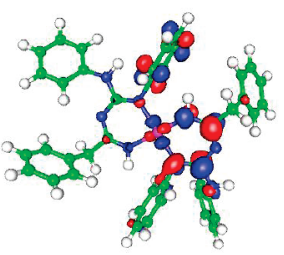

年

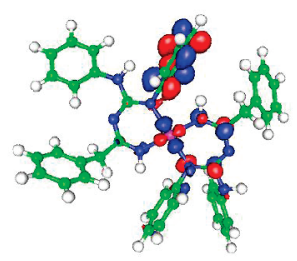

16

$\begin{array}{ccclll}\mathrm{S}_{1} & \text { HOMO } \rightarrow \operatorname{LUMO}(+90 \%) & 2.75 & 450.6 & 0.0631 & \text { MLCT: } 10.37 \% \\ \mathrm{~T}_{1} & \mathrm{HOMO} \rightarrow \operatorname{LUMO}(+96 \%) & 2.40 & 516.7 & 0.0000 & \text { MLCT: } 11.06 \% \\ \text { HOMO } & & & \text { LUMO } & & \end{array}$

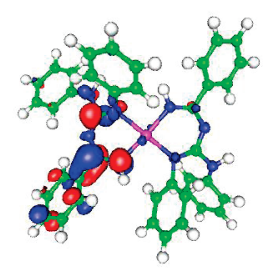

Figure 6. Descriptions, energy gaps, oscillation strengths of $S_{1}$ and $T_{1}$, and HOMO and LUMO of 14-16.

display applications, upon proper derivatization. Work focusing on these projects is underway in our group.

\section{Experimental Section}

Materials and Instrumentation. The guanidine $\mathrm{HN}=\mathrm{C}(\mathrm{NHPh})_{2}$ (Aldrich) and solvents were obtained from commercial sources and used as received. The complexes cis- $\left[\mathrm{PtCl}_{2}(\mathrm{RCN})_{2}\right](\mathrm{R}=$ $\left.\mathrm{Me},{ }^{54} \mathrm{Et}^{55}\right)$ were prepared in accord with the published methods. These compounds contain admixtures of the trans isomers (an isomeric cis:trans ratio obtained by NMR integration is ca. $5: 1$ for $\mathrm{R}=\mathrm{Me}^{54}$ and ca. 6:1 for $\left.\mathrm{R}=\mathrm{Et}^{55}\right)$. The isomerically pure complexes trans- $\left[\mathrm{PtCl}_{2}(\mathrm{RCN})_{2}\right]\left(\mathrm{R}=\mathrm{Et},{ }^{55} \mathrm{CH}_{2} \mathrm{Ph}^{56}\right)$ and cis$\left[\mathrm{PtCl}_{2}\left(\mathrm{PhCH}_{2} \mathrm{CN}\right)_{2}\right]^{56}$ were obtained as previously described. The complex trans- $\left[\mathrm{PtCl}_{2}(\mathrm{PhCN})_{2}\right]$ was obtained upon heating

(54) Fanizzi, F. P.; Intini, F. P.; Maresca, L.; Natile, G. J. Chem. Soc., Dalton Trans. 1990, 199.

(55) Svensson, P.; Lövqvist, K.; Kukushkin, V. Yu.; Oskarsson, Å. Acta Chem. Scand. 1995, 49, 72. Kukushkin, V. Yu.; Oskarsson, Å.; Elding, L. I. Inorg. Synth. 1997, 31, 279. 
Table 5. Crystal Data

\begin{tabular}{|c|c|c|c|c|c|c|c|c|}
\hline & 1 & 2 & 4 & $9^{2+}$ & $10^{2+}$ & 11 & 13 & 14 \\
\hline empirical formula & $\mathrm{C}_{4} \mathrm{H}_{9} \mathrm{Cl}_{2} \mathrm{~N}_{3} \mathrm{Pt}$ & $\mathrm{C}_{6} \mathrm{H}_{13} \mathrm{Cl}_{2} \mathrm{~N}_{3} \mathrm{Pt}$ & $\mathrm{C}_{90} \mathrm{H}_{92} \mathrm{Cl}_{12} \mathrm{~N}_{18} \mathrm{O}_{3} \mathrm{Pt}_{6}$ & $\mathrm{C}_{24} \mathrm{H}_{36} \mathrm{~N}_{12} \mathrm{O}_{14} \mathrm{Pt}$ & $\mathrm{C}_{24} \mathrm{H}_{33} \mathrm{~N}_{11} \mathrm{O}_{14} \mathrm{Pt}$ & $\mathrm{C}_{19} \mathrm{H}_{22} \mathrm{ClN}_{5} \mathrm{Pt}$ & $\mathrm{C}_{27} \mathrm{H}_{22} \mathrm{ClN}_{5} \mathrm{Pt}$ & $\mathrm{C}_{32} \mathrm{H}_{34} \mathrm{~N}_{8} \mathrm{Pt}$ \\
\hline $\mathrm{fw}$ & 365.13 & 393.18 & 3069.76 & 911.74 & 894.70 & 550.96 & 647.04 & 725.76 \\
\hline temp $(\mathrm{K})$ & $120(2)$ & $120(2)$ & $120(2)$ & $120(2)$ & $120(2)$ & $150(2)$ & $120(2)$ & $120(2)$ \\
\hline cryst syst & monoclinic & monoclinic & monoclinic & triclinic & monoclinic & triclinic & triclinic & Ttriclinic \\
\hline space group & $P 2_{1} / c$ & $P 2_{1} / n$ & $P 2{ }_{1} / c$ & $P \overline{1}$ & $P 2 / c$ & $P \overline{1}$ & $P \overline{1}$ & $P \overline{1}$ \\
\hline$a(\AA)$ & $16.0700(12)$ & $7.0744(2)$ & $18.8625(11)$ & $8.8755(4)$ & $23.7788(6)$ & $10.2632(3)$ & $9.1616(5)$ & $5.9465(2)$ \\
\hline$\beta$ (deg) & $123.432(3)$ & 101.901(1) & 103.071(1) & $84.415(2)$ & $104.5010(10)$ & $85.286(2)$ & $105.703(2)$ & $101.928(2)$ \\
\hline$\gamma(\operatorname{deg})$ & 90 & 90 & 90 & $71.220(3)$ & 90 & $67.6680(10)$ & $93.557(3)$ & $103.712(2)$ \\
\hline$V\left(\AA^{3}\right)$ & $1722.9(2)$ & $1021.19(4)$ & $4998.3(3)$ & $1685.58(13)$ & $3193.34(13)$ & $972.52(5)$ & $1193.75(11)$ & $707.99(4)$ \\
\hline $\mathrm{Z}$ & 8 & 4 & 2 & 2 & 4 & 2 & 2 & 1 \\
\hline$\rho_{\text {calcd }}\left(\mathrm{Mg} / \mathrm{m}^{3}\right)$ & 2.815 & 2.557 & 2.040 & 1.796 & 1.861 & 1.881 & 1.800 & 1.702 \\
\hline$\mu(\operatorname{Mo~K\alpha })\left(\mathrm{mm}^{3}\right)$ & 16.840 & 14.215 & 8.742 & 4.246 & 4.480 & 7.364 & 6.015 & 4.992 \\
\hline
\end{tabular}

$$
{ }^{a} \mathrm{R} 1=\sum\left\|F_{\mathrm{o}}|-| F_{\mathrm{c}}\right\| / \sum\left|F_{\mathrm{o}}\right|{ }^{b} \mathrm{wR} 2=\left[\sum\left[w\left(F_{\mathrm{o}}{ }^{2}-F_{\mathrm{c}}{ }^{2}\right)^{2}\right] / \sum\left[w\left(F_{\mathrm{o}}{ }^{2}\right)^{2}\right]\right]^{1 / 2}
$$

$\left[\mathrm{PtCl}_{2}(\mathrm{MeCN})_{2}\right]$ with $\mathrm{PhCN},{ }^{57}$ followed by separation of the admixture of the cis isomer by column chromatography on $\mathrm{SiO}_{2}$ (silica gel $60 \mathrm{~F}_{254}, 0.063-0.200 \mathrm{~mm}$, Merck; eluent is $1 / 20$ (v/v) ethyl acetate $-\mathrm{CHCl}_{3}, R_{f}$ for the trans isomer is 0.68 ). The cis- $\left[\mathrm{PtCl}_{2}(\mathrm{PhCN})_{2}\right]$ complex was separated from the cis/trans isomeric mixture, which was obtained in the reaction ${ }^{58}$ between $\mathrm{K}_{2}\left[\mathrm{PtCl}_{4}\right]$ and $\mathrm{PhCN}$ in water, by column chromatography on $\mathrm{SiO}_{2}$ (silica gel $60 \mathrm{~F}_{254}, 0.063-0.200 \mathrm{~mm}$, Merck; eluent 1/20 ethyl acetate $-\mathrm{CHCl}_{3}, R_{f}$ for the cis isomer is 0.31 ). TLC was done on Merck $60 \mathrm{~F}_{254} \mathrm{SiO}_{2}$ plates.

Elemental analyses were obtained on a Hewlett-Packard 185B carbon hydrogen nitrogen analyzer. DTA/TG measurements were performed using a Perkin-Elmer (Diamond TG/DTA) derivatograph in air at a heating rate of $10{ }^{\circ} \mathrm{C} / \mathrm{min}$ (carrier gas air, $200 \mathrm{~mL} / \mathrm{min}$ ). ESI-TOF mass spectra were obtained on a MX-5310 mass spectrometer. Positive-ion FAB mass spectra of the platinum(II) complexes were obtained on a MS-50C (Kratos) instrument by bombarding 3-nitrobenzyl alcohol matrices of the samples with 8 $\mathrm{keV}$ (ca. $1.28 \times 10^{15} \mathrm{~J}$ ) Xe atoms. Mass calibration for data system acquisition was achieved using CsI. Infrared spectra (4000-400 $\mathrm{cm}^{-1}$ ) were recorded on a Shimadzu FTIR 8400S instrument in $\mathrm{KBr}$ pellets. ${ }^{1} \mathrm{H}$ and ${ }^{13} \mathrm{C}\left\{{ }^{1} \mathrm{H}\right\}$ NMR spectra were measured on a Bruker-DPX 300 spectrometer at ambient temperature.

X-ray Crystal Structure Determinations. The crystals were immersed in cryo oil and mounted in a nylon loop, and the data were measured at a temperature of 120 or $150 \mathrm{~K}$. The X-ray diffraction data were collected by means of a Nonius KappaCCD diffractometer using Mo $\mathrm{K} \alpha$ radiation $(\lambda=0.71073 \AA)$. The Denzo-Scalepack ${ }^{59}$ and EvalCCD ${ }^{60}$ program packages were used for cell refinements and data reductions. All of the structures were

(56) Kukushkin, V. Yu.; Tkachuk, V. M.; Vorobiov-Desiatovsky, N. V Inorg. Synth. 1998, 32, 144.

(57) Makarycheva-Mikhailova, A. V.; Bokach, N. A.; Kukushkin, V. Yu.; Kelly, P. F.; Gilby, L. M.; Kuznetsov, M. L.; Holmes, K. E.; Haukka, M.; Parr, J.; Stonehouse, J. M.; Elsegood, M. R. J.; Pombeiro, A. J. L. Inorg. Chem. 2003, 42, 301.

(58) Fanizzi, F. P.; Intini, F. P.; Natile, G. J. Chem. Soc., Dalton Trans. 1989, 947.

(59) Otwinowski, Z.; Minor, W. Processing of X-ray Diffraction Data Collected in Oscillation Mode. In Methods in Enzymology; Carter, C. W., Sweet, J., Eds.; Academic Press: New York, 1997; Vol. 276, Macromolecular Crystallography, Part A, pp 307-326.

(60) Duisenberg, A. J. M.; Kroon-Batenburg, L. M. J.; Schreurs, A. M. M. J. Appl. Crystallogr. 2003, 36, 220-229. solved by direct methods using SHELXS-97, ${ }^{11}$ SIR2002, or SIR2004 with the WinGX ${ }^{62}$ graphical user interface. An empirical absorption correction was applied to all of the data $\left(S A D A B S^{63}\right.$ or XPREP in SHELXTL ${ }^{64}$ ). Structural refinements were carried out using SHELXL97. ${ }^{65}$ The asymmetric unit of $\mathbf{4}$ contains three independent $\mathrm{Pt}$ molecules, an acetone molecule, and half of a water molecule. In 11 the carbon atoms $\mathrm{C}(4)$ and $\mathrm{C}(5)$ were disordered over two sites with occupancies $0.43 / 0.57$. In $1,2,4,9^{2+}, \mathbf{1 0}^{2+}, \mathbf{1 1}$, and 14 the $\mathrm{NH}$ and $\mathrm{H}_{2} \mathrm{O}$ hydrogen atoms were located from the difference Fourier map but constrained to ride on their parent atom with $U_{\text {iso }}$ being 1.5 times the $U_{\text {eq }}$ value for the parent atom. Other hydrogens were positioned geometrically and constrained to ride on their parent atoms, with $\mathrm{C}-\mathrm{H}=0.95-0.99 \AA, \mathrm{N}-\mathrm{H}=0.88 \AA$, and $U_{\text {iso }}$ being $1.2-1.5$ times the $U_{\text {eq }}$ value for the parent atom. The crystallographic details are summarized in Table 5, and selected bond lengths and angles in Tables $1-3$.

Luminescence Study of 14-16. Steady-state absorption and emission spectra were recorded by a Hitachi (U-3310) spectrophotometer and an Edinburgh (FS920) fluorimeter, respectively. Both the wavelength-dependent excitation and emission responses of the fluorimeter were calibrated. A configuration of the front-face excitation was used to measure the emission of the solid sample, for which the cell was made by assembling two edge-polished quartz plates with various Teflon spacers. A combination of appropriate filters was used to avoid interference from the scattering light. An integrating sphere (Labsphere) was applied to measure the quantum yield in the solid state, with excitation by a $365 \mathrm{~nm}$ $\mathrm{Ar}^{+}$laser line. The resulting luminescence was acquired with a charge-coupled detector (Princeton Instruments, Model CCD-1100) for subsequent quantum yield analyses. Lifetime studies were performed with an Edinburgh FL 900 photon-counting system with a hydrogen-filled or nitrogen lamp as the excitation source.

Theoretical Methodology. All calculations were done with the Gaussian 03 program. ${ }^{66}$ The geometries of complexes 14-16 were

(61) Sheldrick, G. M. SHELXS-97, Program for Crystal Structure Determination, University of Göttingen, Göttingen, Germany, 1997.

(62) Farrugia, L. J. J. Appl. Crystallogr. 1999, 32, 837.

(63) Sheldrick, G. M. SADABS - Bruker Nonius Scaling and Absorption Correction, v 2.10; Bruker AXS, Inc., Madison, WI, 2003.

(64) Sheldrick, G. M. SHELXTL v. 6.14-1; Bruker AXS, Inc., Madison, WI, 2005

(65) Sheldrick, G. M. SHELXL-97, Program for Crystal Structure Refinement; University of Göttingen, Göttingen, Germany, 1997. 
calculated by the hybrid DFT B3LYP functional. ${ }^{67}$ Except for the platinum element, the split-valence basis set $6-31 G^{*}$ was chosen to describe the other elements. The pseudopotential LANL2 combines a valence double- $\zeta$ basis set; i.e., LANL2DZ was chosen for platinum in order to describe its relativistic effect. ${ }^{68}$ All minima were identified positively, as the number of imaginary frequencies is zero. On the basis of the converged geometries, the vertical excitation energies were calculated by TDB3LYP with the same basis set mentioned above. ${ }^{69}$

Synthetic Work. Reaction of cis-[ $\left.\operatorname{PtCl}_{2}(\operatorname{RCN})_{2}\right]$ and DPG (2 equiv). $\mathrm{HN}=\mathrm{C}(\mathrm{NHPh})_{2}(53 \mathrm{mg}, 0.25 \mathrm{mmol})$ was added to a solution of cis-[ $\left.\mathrm{PtCl}_{2}(\mathrm{RCN})_{2}\right](0.12 \mathrm{mmol})$ in $\mathrm{MeCN}(1.2 \mathrm{~mL}$; R $=\mathrm{Me}), \mathrm{EtCN}(1 \mathrm{~mL} ; \mathrm{R}=\mathrm{Et})$, or $\mathrm{CH}_{2} \mathrm{Cl}_{2}\left(1 \mathrm{~mL} ; \mathrm{R}=\mathrm{CH}_{2} \mathrm{Ph}, \mathrm{Ph}\right)$, and the mixture was left to stand for $2 \mathrm{~h}$ at $40{ }^{\circ} \mathrm{C}$ and then (for digestion of the initially formed precipitate) for $22 \mathrm{~h}$ at $20-25^{\circ} \mathrm{C}$ $(\mathrm{R}=\mathrm{Me}, \mathrm{Et})$ (crystals started to release already after 5-10 min) or $24 \mathrm{~h}$ at $20-25^{\circ} \mathrm{C}\left(\mathrm{R}=\mathrm{CH}_{2} \mathrm{Ph}, \mathrm{Ph}\right)$ (pale yellow precipitate immediately began to release for $\mathrm{R}=\mathrm{CH}_{2} \mathrm{Ph}$ ). Pale yellow crystals $(\mathrm{R}=\mathrm{Me}, \mathrm{Et})$ or a pale yellow precipitate $\left(\mathrm{R}=\mathrm{CH}_{2} \mathrm{Ph}\right)$ was filtered off, washed with two $0.5 \mathrm{~mL}$ portions of $\mathrm{Me}_{2} \mathrm{CO}$ and one $0.5 \mathrm{~mL}$ portion of $\mathrm{Et}_{2} \mathrm{O}$, and dried in air at $20-25{ }^{\circ} \mathrm{C}$. The greenish yellow solution formed for $\mathrm{R}=\mathrm{Ph}$ was evaporated to dryness, and the green oily residue was crystallized under a layer of hexane $(1 \mathrm{~mL})$ to form the solid yellow powder, which was washed with two 1 $\mathrm{mL}$ portions of $\mathrm{Et}_{2} \mathrm{O}$, dissolved in $\mathrm{CHCl}_{3}$, purified by column chromatography on $\mathrm{SiO}_{2}$ (silica gel $60 \mathrm{~F}_{254}, 0.063-0.200 \mathrm{~mm}$, Merck; eluent $\left.1 / 10 \mathrm{Me}_{2} \mathrm{CO}-\mathrm{CHCl}_{3}, R_{f}=0.40\right)$, and dried in air at 20-25 ${ }^{\circ} \mathrm{C}$. Yields are $19 \mathrm{mg}, 44 \%(\mathrm{R}=\mathrm{Me}), 25 \mathrm{mg}, 54 \%(\mathrm{R}=$ $\mathrm{Et}), 36 \mathrm{mg}, 58 \%\left(\mathrm{R}=\mathrm{CH}_{2} \mathrm{Ph}\right)$, and $17 \mathrm{mg}, 30 \%(\mathrm{R}=\mathrm{Ph})$.

1. Anal. Calcd for $\mathrm{C}_{4} \mathrm{H}_{9} \mathrm{~N}_{3} \mathrm{Cl}_{2} \mathrm{Pt}$ : C, 13.16; H, 2.48; N, 11.51 . Found: C, 13.19; H, 2.48; N, 11.59. ESI - -MS $(\mathrm{m} / \mathrm{z}): 364[\mathrm{M}-$ $\mathrm{H}]^{-}$. $\mathrm{FAB}^{+}-\mathrm{MS}(\mathrm{m} / \mathrm{z}): 388[\mathrm{M}+\mathrm{Na}]^{+}, 365[\mathrm{M}]^{+}, 329[\mathrm{M}-\mathrm{Cl}]^{+}$. TLC: $R_{f}=0.69$ (eluent $\left.1 / 5 \mathrm{MeOH}-\mathrm{CHCl}_{3}\right)$. IR $(\mathrm{KBr}$, selected bands, $\mathrm{cm}^{-1}$ ): 3338 (m), 3282 (s), 3248 (s), 3149 (s), 3043 (m-s), $v(\mathrm{~N}-\mathrm{H}) ; 2989(\mathrm{~m}), v(\mathrm{~N}-\mathrm{H}$ and/or $\mathrm{C}-\mathrm{H}$ from Me); $2773(\mathrm{~m}-\mathrm{w})$, $v\left(\mathrm{C}-\mathrm{H}\right.$ from Me); $1672(\mathrm{~s}), 1545(\mathrm{~s}), v(\mathrm{C}=\mathrm{N}) .{ }^{1} \mathrm{H}$ NMR (DMSO$\left.d_{6}, \delta\right): 10.86(\mathrm{~s}, 1 \mathrm{H}, \mathrm{NH}), 9.94(\mathrm{~s}, \mathrm{br}, 2 \mathrm{H}, \mathrm{NH}=\mathrm{CMe}), 1.90(\mathrm{~s}, 6 \mathrm{H}$, $\left.\mathrm{CH}_{3}\right) .{ }^{13} \mathrm{C}\left\{{ }^{1} \mathrm{H}\right\}$ NMR (DMSO- $\left.d_{6}, \delta\right): 152.37(\mathrm{C}=\mathrm{N}), 21.59\left(\mathrm{CH}_{3}\right)$. Crystals suitable for an X-ray diffraction study were obtained directly from the reaction mixture.

2. Anal. Calcd for $\mathrm{C}_{6} \mathrm{H}_{13} \mathrm{~N}_{3} \mathrm{Cl}_{2} \mathrm{Pt}$ : C, $18.32 ; \mathrm{H}, 3.31 ; \mathrm{N}, 10.68$. Found: C, 18.76; H, 3.38; N, 10.65. ESI- ${ }^{-} \mathrm{MS}(\mathrm{m} / \mathrm{z}): 392[\mathrm{M}-$ $\mathrm{H}]^{-}$. $\mathrm{FAB}^{+}-\mathrm{MS}(\mathrm{m} / \mathrm{z}): 416[\mathrm{M}+\mathrm{Na}]^{+}, 393[\mathrm{M}]^{+}, 357[\mathrm{M}-\mathrm{Cl}]^{+}$, $321[\mathrm{M}-\mathrm{HCl}-\mathrm{Cl}]^{+}$. TLC: $R_{f}=0.43$ (eluent $1 / 10 \mathrm{MeOH}-\mathrm{CHCl}_{3}$ ). IR ( $\mathrm{KBr}$, selected bands, $\mathrm{cm}^{-1}$ ): 3325 (m), 3284 (s), 3234 (s), 3140

(66) Frisch, M. J.; Trucks, G. W.; Schlegel, H. B.; Scuseria, G. E.; Robb, M. A.; Cheeseman, J. R.; Montgomery, J. A. Jr.; Vreven, T.; Kudin, K. N.; Burant, J. C.; Millam, J. M.; Iyengar, S. S.; Tomasi, J.; Barone, V.; Mennucci, B.; Cossi, M.; Scalmani, G.; Rega, N.; Petersson, G. A.; Ehara, M.; Toyota, K.; Hada, M.; Fukuda, R.; Hasegawa, J.; Ishida, M.; Nakajima, T.; Kitao, O.; Nakai, H.; Honda, Y.; Nakatsuji, H.; Li, X.; Knox, J. E.; Hratchian, H. P.; Cross, J. B.; Adamo, C.; Jaramillo, J.; Cammi, R.; Pomelli, C.; Gomperts, R.; Stratmann, R. E.; Ochterski, J.; Ayala, P. Y.; Morokuma, K.; Salvador, P.; Dannenberg, J. J.; Zakrzewski, V. G.; Dapprich, S.; Daniels, A. D.; Strain, M. C.; Farkas, O.; Malick, D. K.; Rabuck, A. D.; Raghavachari, K.; Foresman, J. B.; Ortiz, J. V.; Cui, Q.; Baboul, A. G.; Clifford, S.; Cioslowski, J.; Stefanov, B. B.; Liu, G.; Liashenko, A.; Piskorz, P.; Komaromi, I.; Martin, R. L.; Fox, D. J.; Keith, T.; Al-Laham, M. A.; Peng, C. Y.; Nanayakkara, A.; Challacombe, M.; Gill, P. M. W.; Johnson, B.; Chen, W.; Wong, M. W.; Gonzalez, C.; Pople, J. A. Gaussian 03, version A.1; Gaussian, Inc., Pittsburgh, PA, 2002.

(67) (a) Becke, A. D. Phys. Rev. A 1988, 38, 3098. (b) Lee, C.; Yang, W.; Parr, R. G. Phys. Rev. B 1988, 37, 785.

(68) Hay, P. J.; Wadt, W. R. J. Chem. Phys. 1985, 82, 299.

(69) Stratmann, R. E.; Scuseria, G. E.; Frisch, M. J. J. Chem. Phys. 1998, 109,8218 . $(\mathrm{s}), v(\mathrm{~N}-\mathrm{H}) ; 3028(\mathrm{~m}), v(\mathrm{~N}-\mathrm{H}$ and/or $\mathrm{C}-\mathrm{H}$ from $\mathrm{Et}) ; 2993(\mathrm{~m})$, 2978 (m), 2941 (m), 2879 (m-w), 2758 (m-w), $v(\mathrm{C}-\mathrm{H}$ from Et); $1664(\mathrm{~s}), 1543(\mathrm{~s}), v(\mathrm{C}=\mathrm{N}) .{ }^{1} \mathrm{H}$ NMR (DMSO-d $\left.d_{6}, \delta\right): 10.87(\mathrm{~s}$, 1H, NH), 9.87 (s, br, 2H, NH=CEt), 2.39 (q, $7.3 \mathrm{~Hz}, 4 \mathrm{H}, \mathrm{CH}_{2}$ ), 1.09 (t, $\left.7.3 \mathrm{~Hz}, 6 \mathrm{H}, \mathrm{CH}_{3}\right)(E t) .{ }^{13} \mathrm{C}\left\{{ }^{1} \mathrm{H}\right\} \mathrm{NMR}$ (DMSO- $\left.d_{6}, \delta\right): 157.26$ $(\mathrm{C}=\mathrm{N}), 28.73\left(\mathrm{CH}_{2}\right), 11.73\left(\mathrm{CH}_{3}\right)(\mathrm{Et})$. Crystals suitable for an $\mathrm{X}$-ray diffraction study were obtained directly from the reaction mixture.

3. Anal. Calcd for $\mathrm{C}_{16} \mathrm{H}_{17} \mathrm{~N}_{3} \mathrm{Cl}_{2} \mathrm{Pt}$ : C, 37.15; H, 3.31; N, 8.12. Found: C, 37.02; H, 3.39; N, 7.91. ESI--MS $(\mathrm{m} / \mathrm{z})$ : $516[\mathrm{M}-\mathrm{H}]^{-}$. $\mathrm{FAB}^{+}-\mathrm{MS}(\mathrm{m} / \mathrm{z}): 556[\mathrm{M}+\mathrm{K}]^{+}, 540[\mathrm{M}+\mathrm{Na}]^{+}, 517[\mathrm{M}]^{+}, 482$ $[\mathrm{M}-\mathrm{Cl}]^{+}$. TLC: $R_{f}=0.33$ (eluent $\left.1 / 10 \mathrm{MeOH}-\mathrm{CHCl}_{3}\right)$. IR $(\mathrm{KBr}$, selected bands, $\left.\mathrm{cm}^{-1}\right)$ : 3309 (m-s), 3256 (m-s), 3166 (m-s), $v(\mathrm{~N}-\mathrm{H}) ; 3043(\mathrm{~m}), v(\mathrm{~N}-\mathrm{H}$ and/or $\mathrm{C}-\mathrm{H}$ from $\mathrm{Ar}) ; 2908(\mathrm{~m}-\mathrm{w})$, $2732(\mathrm{w}), v\left(\mathrm{C}-\mathrm{H}\right.$ from $\left.\mathrm{CH}_{2} \mathrm{Ph}\right) ; 1672(\mathrm{~s}), v(\mathrm{C}=\mathrm{N}) ; 1592(\mathrm{w}), 1543$ (m-s), $v(\mathrm{C}=\mathrm{N}$ and/or $\mathrm{C}=\mathrm{C}$ from $\mathrm{Ar}) ; 745(\mathrm{~m}-\mathrm{s}), 701(\mathrm{~s}), \delta(\mathrm{C}-\mathrm{H}$ from Ar). ${ }^{1} \mathrm{H}$ NMR (DMSO- $d_{6}, \delta$ ): $11.28(\mathrm{~s}, 1 \mathrm{H}, \mathrm{NH}), 10.22(\mathrm{~s}$, $\left.2 \mathrm{H}, \mathrm{NH}=\mathrm{CCH}_{2} \mathrm{Ph}\right), 7.31(\mathrm{~s}, 10 \mathrm{H}, \mathrm{Ph}), 3.78\left(\mathrm{~s}, 4 \mathrm{H}, \mathrm{CH}_{2} \mathrm{Ph}\right) .{ }^{13} \mathrm{C}\left\{{ }^{1} \mathrm{H}\right\}$ NMR (DMSO- $\left.d_{6}, \delta\right): 154.13(\mathrm{C}=\mathrm{N}), 134.28\left(C_{\text {ipso }}\right), 129.53,129.36$, 126.13 (carbons in $\mathrm{Ph}$ ).

$\mathbf{4} \cdot \mathbf{2}^{1 / 2} \mathrm{H}_{2} \mathrm{O}$. The hydrate was obtained using undried solvents, and the isolated solid was dried in air at $20-25{ }^{\circ} \mathrm{C}$. Anal. Calcd for $\mathrm{C}_{14} \mathrm{H}_{13} \mathrm{~N}_{3} \mathrm{Cl}_{2} \mathrm{Pt} \cdot 2 \frac{1}{2} \mathrm{H}_{2} \mathrm{O}: \mathrm{C}, 31.52 ; \mathrm{H}, 3.40 ; \mathrm{N}, 7.88$. Found: $\mathrm{C}$, 31.78; H, 3.65; N, 8.07. ESI--MS $(m / z): 488[\mathrm{M}-\mathrm{H}]^{-}$. TLC: $R_{f}$ $=0.40$ (eluent $1 / 5 \mathrm{Me}_{2} \mathrm{CO}-\mathrm{CHCl}_{3}$ ). IR ( $\mathrm{KBr}$, selected bands, $\left.\mathrm{cm}^{-1}\right)$ : $3396(\mathrm{w}), 3347(\mathrm{w}), 3233(\mathrm{~m}-\mathrm{w}), v(\mathrm{~N}-\mathrm{H}) ; 3057$ (m-w), $v(\mathrm{~N}-\mathrm{H}$ and/or $\mathrm{C}-\mathrm{H}$ from $\mathrm{Ph}) ; 1624(\mathrm{~s}), v(\mathrm{C}=\mathrm{N}) ; 1594(\mathrm{~s}), 1539$ (s), $v(\mathrm{C}=\mathrm{N}$ and/or $\mathrm{C}=\mathrm{C}$ from $\mathrm{Ar}) ; 755(\mathrm{~m}-\mathrm{s}), 695(\mathrm{~s}), \delta(\mathrm{C}-\mathrm{H}$ from Ar). ${ }^{1} \mathrm{H}$ NMR $\left(\mathrm{Me}_{2} \mathrm{CO}-d_{6}, \delta\right): 10.65(\mathrm{~s}, \mathrm{br}, 1 \mathrm{H}, \mathrm{N} H), 9.45$ (s, br, $2 \mathrm{H}, \mathrm{N} H=\mathrm{CPh}), 7.94(\mathrm{~d}, 4 \mathrm{H}, o-\mathrm{Ph}), 7.72(\mathrm{t}, 2 \mathrm{H}, p-\mathrm{Ph}), 7.57$ (t, 4H, $m$-Ph). ${ }^{13} \mathrm{C}\left\{{ }^{1} \mathrm{H}\right\}$ NMR $\left(\mathrm{CDCl}_{3}, \delta\right): 157.67(\mathrm{C}=\mathrm{N}), 136.68\left(C_{\mathrm{ipso}}\right)$, 129.61, 129.04, 126.77 (carbons in $\mathrm{Ph}$ ). Crystals of $\left[\mathrm{PtCl}_{2^{-}}\right.$ $\{N \mathrm{HC}(\mathrm{Ph}) \mathrm{NHC}(\mathrm{Ph})=N \mathrm{H}\}]_{3} \cdot \mathrm{Me}_{2} \mathrm{CO} \cdot 1 / 2 \mathrm{H}_{2} \mathrm{O}$ suitable for an X-ray diffraction study were obtained by slow evaporation at $20-25{ }^{\circ} \mathrm{C}$ of a $\mathrm{CH}_{2} \mathrm{Cl}_{2}-\mathrm{Me}_{2} \mathrm{CO}(1 / 1, \mathrm{v} / \mathrm{v})$ solution.

Reaction of cis-[ $\left.\mathbf{P t C l}_{2}(\mathbf{R C N})_{2}\right]\left(\mathbf{R}=\mathbf{E t}, \mathrm{CH}_{2} \mathbf{P h}, \mathbf{P h}\right)$ and DPG (2 equiv) at $-20{ }^{\circ} \mathbf{C}$. cis- $\left[\mathrm{PtCl}_{2}(\mathrm{RCN})_{2}\right]\left(\mathrm{R}=\mathrm{Et}, \mathrm{CH}_{2} \mathrm{Ph}\right.$, $\mathrm{Ph})(0.12 \mathrm{mmol})$ and $\mathrm{HN}=\mathrm{C}(\mathrm{NHPh})_{2}(52.7 \mathrm{mg}, 0.25 \mathrm{mmol})$ were dissolved in $\mathrm{CH}_{2} \mathrm{Cl}_{2}$ at $-20{ }^{\circ} \mathrm{C}$ and left to stand for $2 \mathrm{~h}$ with slow heating to $4{ }^{\circ} \mathrm{C}$, and then the reaction mixture was kept for $24 \mathrm{~h}$ at $4{ }^{\circ} \mathrm{C}$. The pale yellow precipitate that formed was filtered off, washed with two $0.5 \mathrm{~mL}$ portions of $\mathrm{CH}_{2} \mathrm{Cl}_{2}$, and one $0.5 \mathrm{~mL}$ portion of $\mathrm{Et}_{2} \mathrm{O}$, and dried in air at $20-25{ }^{\circ} \mathrm{C}$. It was weighed, fully dissolved in DMSO- $d_{6}$, and analyzed by ${ }^{1} \mathrm{H}$ NMR. Molar ratios of complexes $\mathbf{2}$ and $\mathbf{5}$ and of $\mathbf{3}$ and $\mathbf{6}$ obtained by the NMR integration are ca. 8:1 and ca. 1:1, respectively. Yields of 2, 5, 3, and $\mathbf{6}$ were calculated on the basis of ${ }^{1} \mathrm{H}$ NMR data. The yields are $35 \%$ (2) and $4 \%(5), 26 \%(3)$, and $26 \%(6)$. In the case of cis- $\left[\mathrm{PtCl}_{2}-\right.$ $\left.(\mathrm{PhCN})_{2}\right]$, the conductance of the reaction with DPG at $-20{ }^{\circ} \mathrm{C}$ in $\mathrm{CH}_{2} \mathrm{Cl}_{2}$ led to formation of the tailoring product formulas. The latter exhibit very high solubility, and they were not isolated as solids but were characterized in the solution by ESI-MS.

5. We did not obtain sufficient amount of this material (see Results and Discussion) to conduct $\mathrm{C}, \mathrm{H}, \mathrm{N}$ analyses. $\mathrm{ESI}^{+}$-MS $(\mathrm{m} / \mathrm{z}): 492[\mathrm{M}+\mathrm{Na}]^{+}, 508[\mathrm{M}+\mathrm{K}]^{+} . \mathrm{ESI}^{-}-\mathrm{MS}(\mathrm{m} / \mathrm{z}): 392[\mathrm{M}-$ $\mathrm{Ph}]^{-} .{ }^{1} \mathrm{H}$ NMR (DMSO- $\left.d_{6}, \delta\right): 10.28(\mathrm{~s}, \mathrm{br}, 2 \mathrm{H}, \mathrm{NH}), 7.58(\mathrm{~m}$, 2H), $7.67(\mathrm{~m}, 3 \mathrm{H})(\mathrm{Ph}), 2.03\left(\mathrm{q}, 7.5 \mathrm{~Hz}, 4 \mathrm{H}, \mathrm{CH}_{2}\right), 0.83$ (t, $7.5 \mathrm{~Hz}$, $\left.6 \mathrm{H}, \mathrm{CH}_{3}\right)(\mathrm{Et})$.

6. We did not obtain sufficient amount of this material (see Results and Discussion) to conduct $\mathrm{C}, \mathrm{H}, \mathrm{N}$ analyses. $\mathrm{ESI}^{+}-\mathrm{MS}$ $(\mathrm{m} / \mathrm{z}): 616[\mathrm{M}+\mathrm{Na}]^{+}$. ESI ${ }^{-}-\mathrm{MS}(\mathrm{m} / \mathrm{z}): 516[\mathrm{M}-\mathrm{Ph}]^{-} .{ }^{1} \mathrm{H} \mathrm{NMR}$ $\left(\mathrm{DMSO}-d_{6}, \delta\right): 10.55(\mathrm{~s}, \mathrm{br}, 2 \mathrm{H}, \mathrm{NH}), 7.36(\mathrm{t}, 1 \mathrm{H}), 7.15(\mathrm{t}, 2 \mathrm{H})$, $6.93(\mathrm{~d}, 2 \mathrm{H})(\mathrm{Ph}), 7.22(\mathrm{t}, 6 \mathrm{H}), 6.73(\mathrm{~d}, 4 \mathrm{H})\left(\mathrm{CH}_{2} \mathrm{Ph}\right), 3.46(\mathrm{~s}, 4 \mathrm{H}$, 
$\left.\mathrm{CH}_{2} \mathrm{Ph}\right) .{ }^{13} \mathrm{C}\left\{{ }^{1} \mathrm{H}\right\}$ NMR (DMSO- $\left.d_{6}, \delta\right): 156.01(\mathrm{C}=\mathrm{N}), 137.80$, 130.77 ( $\left.C_{\text {ipso }}\right), 133.18,131.14,129.62,129.40,128.90,128.12$ (carbons in $\mathrm{Ar}), 42.97\left(\mathrm{CH}_{2} \mathrm{Ph}\right)$.

Reaction of cis-[ $\left.\mathrm{PtCl}_{2}(\mathbf{R C N})_{2}\right]\left(\mathbf{R}=\mathbf{E t}, \mathrm{CH}_{2} \mathbf{P h}, \mathbf{P h}\right)$ and DPG (4 equiv) at 20-25 ${ }^{\circ} \mathbf{C}$. cis- $\left[\mathrm{PtCl}_{2}\left(\mathrm{PhCH}_{2} \mathrm{CN}\right)_{2}\right](0.12 \mathrm{mmol})$ and $\mathrm{HN}=\mathrm{C}(\mathrm{NHPh})_{2}(52.7 \mathrm{mg}, 0.25 \mathrm{mmol})$ were dissolved in $\mathrm{CH}_{2} \mathrm{Cl}_{2}$ and left to stand for $24 \mathrm{~h}$ at $20-25{ }^{\circ} \mathrm{C}$. The pale yellow precipitate that formed was filtered off, washed with two $0.5 \mathrm{~mL}$ portions of $\mathrm{Me}_{2} \mathrm{CO}$ and one $0.5 \mathrm{~mL}$ portion of $\mathrm{Et}_{2} \mathrm{O}$, and dried in air at $20-25{ }^{\circ} \mathrm{C}$. The yield of 6 is $6 \mathrm{mg}, 9 \%$. The filtrate, as verified by means of both ${ }^{1} \mathrm{H}$ NMR and TLC methods, contains a broad mixture of as yet unidentified products but does not contain 6. It was determined by ESI-MS that the filtrates contain products of the $\mathrm{NH}$ tailoring with substitution of two chloride $\mathrm{Cl}^{-}$ligands by the bis(guanidine) $\mathrm{PhN}=\mathrm{C}(\mathrm{NHPh}) \mathrm{N}=\mathrm{C}(\mathrm{NHPh})_{2}(\mathrm{~m} / \mathrm{z}, 743[\mathrm{M}+$ $\left.\mathrm{H}_{2} \mathrm{O}\right]^{+}, 727[\mathrm{M}+2 \mathrm{H}]^{+}, 708\left[\mathrm{M}-\mathrm{NH}_{3}\right]^{+}, 672\left[\mathrm{M}+2 \mathrm{H}-\mathrm{EtCN}^{+}\right.$ $(\mathrm{R}=\mathrm{Et}) ; 868\left[\mathrm{M}+\mathrm{H}_{2} \mathrm{O}\right]^{+}, 850[\mathrm{M}]^{+}\left(\mathrm{R}=\mathrm{CH}_{2} \mathrm{Ph}\right) ; 839[\mathrm{M}+$ $\left.\left.\mathrm{H}_{2} \mathrm{O}\right]^{+}, 822[\mathrm{M}+\mathrm{H}]^{+}(\mathrm{R}=\mathrm{Ph})\right)$ and substitution of one $\mathrm{Cl}^{-}$ligand by $\mathrm{HN}=\mathrm{C}(\mathrm{NHPh})_{2}\left(\mathrm{~m} / \mathrm{z}, 569[\mathrm{M}+\mathrm{H}]^{+}(\mathrm{R}=\mathrm{Et}) ; 693[\mathrm{M}+\mathrm{H}]^{+}\right.$, $691[\mathrm{M}-\mathrm{H}]^{-}\left(\mathrm{R}=\mathrm{CH}_{2} \mathrm{Ph}\right) ; 665[\mathrm{M}+\mathrm{H}]^{+}, 663[\mathrm{M}-\mathrm{H}]^{-}(\mathrm{R}=$ $\mathrm{Ph})$ ).

Synthesis of $\left[\mathrm{Pt}(\text { tmeda })(\mathrm{EtCN})_{2}\right]^{2+}$ and Its Reaction with $\mathrm{NH}_{3}$ and DPG. 7. This compound was obtained by the reaction of $\mathrm{K}_{2}\left[\mathrm{PtCl}_{4}\right]$ with $\mathrm{KI}$ followed by the addition of tmeda (yield $86 \%$; see the Supporting Information). ${ }^{38}$ TLC on Merck $60 \mathrm{~F}_{254} \mathrm{SiO}_{2}$ plates: $R_{f}=0.39$ (eluent $\mathrm{CHCl}_{3}-\mathrm{Me}_{2} \mathrm{CO}, 5 / 2 \mathrm{v} / \mathrm{v}$ ), one spot. IR (KBr, selected bands, $\left.\mathrm{cm}^{-1}\right): 3016(\mathrm{~m}-\mathrm{w}), 2974$ (m-w), 2914 (s) $v(\mathrm{~N}-\mathrm{H}$ and/or $\mathrm{C}-\mathrm{H}) .{ }^{1} \mathrm{H}$ NMR (DMSO- $d_{6}, \delta$ ): 2.97 (s, $12 H$, $\left.\mathrm{N}-\mathrm{CH}_{3}\right), 2.77\left(\mathrm{~s}, 4 \mathrm{H}, \mathrm{N}-\mathrm{CH}_{2}\right) .{ }^{13} \mathrm{C}\left\{{ }^{1} \mathrm{H}\right\} \mathrm{NMR}$ (DMSO- $d_{6}, \delta$ ): $64.29\left(\mathrm{~N}-\mathrm{CH}_{2}\right), 53.57\left(\mathrm{~N}-\mathrm{CH}_{3}\right)$.

8・(OTf $)_{2} \cdot \mathrm{AgSO}_{3} \mathrm{CF}_{3}(0.58 \mathrm{~g}, 2.23 \mathrm{mmol})$ was added to a suspension of 7 (0.62 $\mathrm{g}, 1.10 \mathrm{mmol})$ in $\mathrm{EtCN}(4 \mathrm{~mL})$, and the mixture was stirred in the dark at room temperature for $12 \mathrm{~h}$, whereupon it was filtered to remove the solid $\mathrm{AgI}$ and the solvent was evaporated to dryness under vacuum to give a pale yellow oily residue. The latter was dissolved in a $\mathrm{CH}_{2} \mathrm{Cl}_{2}-\mathrm{Me}_{2} \mathrm{CO}$ solvent mixture (2/1 v/v), and the released solid AgI was centrifugated and separated by decantation. The solution was evaporated under vacuum at $20-25{ }^{\circ} \mathrm{C}$ to give a colorless oily residue, which was dried under vacuum at $20-25^{\circ} \mathrm{C}$. The residue was used for further synthetic transformations. $\mathrm{ESI}^{+}-\mathrm{MS}(\mathrm{m} / \mathrm{z}): 439\left[\mathrm{M}+\mathrm{H}_{2} \mathrm{O}\right]^{+}, 384$ $\left[\mathrm{M}-\mathrm{EtCN}+\mathrm{H}_{2} \mathrm{O}\right]^{+}$. IR (KBr, selected bands, $\left.\mathrm{cm}^{-1}\right): 2997(\mathrm{~m}-$ w), 2961 (m-w), $v(\mathrm{C}-\mathrm{H}$ from $\mathrm{Et}) ; 2187(\mathrm{w}), v(\mathrm{C} \equiv \mathrm{N}) ; 1266$ (vs), 1165 (s), 1032 (s), $v\left(\mathrm{C}-\mathrm{N}\right.$ from the tmeda). ${ }^{1} \mathrm{H} \mathrm{NMR}\left(\mathrm{Me}_{2} \mathrm{CO}-d_{6}\right.$, $\delta): 3.28\left(\mathrm{~s}, 4 \mathrm{H}, \mathrm{N}-\mathrm{CH}_{2}\right), 3.23\left(\mathrm{~s}, 12 \mathrm{H}, \mathrm{N}-\mathrm{CH}_{3}\right), 2.96\left(\mathrm{q}, J_{\mathrm{HH}}=\right.$ $\left.7.3 \mathrm{~Hz}, 4 \mathrm{H},-\mathrm{CH}_{2} \mathrm{CH}_{3}\right), 1.45\left(\mathrm{t}, \mathrm{J}_{\mathrm{HH}}=7.3 \mathrm{~Hz}, 6 \mathrm{H},-\mathrm{CH}_{2} \mathrm{CH}_{3}\right)$. ${ }^{13} \mathrm{C}\left\{{ }^{1} \mathrm{H}\right\} \mathrm{NMR}\left(\mathrm{Me}_{2} \mathrm{CO}-d_{6}, \delta\right): 65.64\left(\mathrm{~N}-\mathrm{CH}_{2}\right), 53.72\left(\mathrm{~N}-\mathrm{CH}_{3}\right)$, $13.41\left(-\mathrm{CH}_{2} \mathrm{CH}_{3}\right), 9.48\left(-\mathrm{CH}_{2} \mathrm{CH}_{3}\right)$.

9.(OTf) $)_{2}$ A solution of the bis(nitrile) complex cis-[Pt(tmeda) $\left.(\mathrm{EtCN})_{2}\right]\left[\mathrm{SO}_{3} \mathrm{CF}_{3}\right]_{2}$ (prepared from cis- $\left[\mathrm{PtI}_{2}\right.$ (tmeda)] (1.10 mmol) as described above) in a $\mathrm{CH}_{2} \mathrm{Cl}_{2}-\mathrm{Me}_{2} \mathrm{CO}$ solution $(2 / 1 \mathrm{v} / \mathrm{v}$, $2 \mathrm{~mL}$ ) was treated with an excess of gaseous ammonia for $6 \mathrm{~h}$ and stirred at room temperature. The colorless solution was evaporated to dryness under vacuum at $20-25{ }^{\circ} \mathrm{C}$ to give a pale yellow oily residue, which was crystallized under a layer of $\mathrm{Et}_{2} \mathrm{O}$ to furnish the colorless solid. The latter was washed with two $2 \mathrm{~mL}$ portions of $\mathrm{Et}_{2} \mathrm{O}$ (with decantation) and dried under vacuum at $20-25{ }^{\circ} \mathrm{C}$. The yield is $0.70 \mathrm{~g}, 85 \%$.

Anal. Calcd for $\mathrm{PtC}_{14} \mathrm{H}_{32} \mathrm{~N}_{6} \mathrm{~F}_{6} \mathrm{~S}_{2} \mathrm{O}_{6}: \mathrm{C}, 22.31 ; \mathrm{H}, 4.28 ; \mathrm{N}, 11.15$. Found C, 22.68; H, 4.31; N, 10.46. FAB ${ }^{+}-\mathrm{MS}(\mathrm{m} / \mathrm{z}): 381[\mathrm{M}-\mathrm{L}$ $-2 \mathrm{H}]^{+}, 115[\text { tmeda }-\mathrm{H}]^{+}, 72[\mathrm{~L}]^{+}$. IR $(\mathrm{KBr}$, selected bands, $\left.\mathrm{cm}^{-1}\right)$ : $3403(\mathrm{~m}), 3338(\mathrm{~m}), 3295(\mathrm{~m}), 3242(\mathrm{~m}), v(\mathrm{~N}-\mathrm{H}) ; 2991$ (m-w), 2942 (m), v(C-H from Et); 1659 (s), $1616(\mathrm{~s}), v(\mathrm{C}=\mathrm{N})$;
1229 (s), $1166(\mathrm{~s}), 1026(\mathrm{~s}), v(\mathrm{C}-\mathrm{N}$ from the amidine or tmeda). ${ }^{1} \mathrm{H}$ NMR $\left(\mathrm{Me}_{2} \mathrm{CO}-d_{6}, \delta\right): 7.43$ (s, br, $\left.2 \mathrm{H},-\mathrm{NH}_{2}\right), 7.07$ (s, br, $2 \mathrm{H}$, $\left.-\mathrm{NH}_{2}\right), 6.68(\mathrm{~s}, \mathrm{br}, 2 \mathrm{H},-\mathrm{NH}=\mathrm{C}-), 3.08\left(\mathrm{~s}, 4 \mathrm{H}, \mathrm{N}-\mathrm{CH}_{2}\right), 2.97$ $\left(\mathrm{s}, 12 \mathrm{H}, \mathrm{N}-\mathrm{CH}_{3}\right), 2.51\left(\mathrm{q}, J_{\mathrm{HH}}=7.3 \mathrm{~Hz}, 4 \mathrm{H},-\mathrm{CH}_{2} \mathrm{CH}_{3}\right), 1.21(\mathrm{t}$, $\left.J_{\mathrm{HH}}=7.3 \mathrm{~Hz}, 6 \mathrm{H},-\mathrm{CH}_{2} \mathrm{CH}_{3}\right) .{ }^{13} \mathrm{C}\left\{{ }^{1} \mathrm{H}\right\} \mathrm{NMR}\left(\mathrm{Me}_{2} \mathrm{CO}-d_{6}, \delta\right)$ : $173.80 \quad(\mathrm{C}=\mathrm{N}), \quad 64.28 \quad\left(\mathrm{~N}-\mathrm{CH}_{2}\right), \quad 51.42 \quad\left(\mathrm{~N}-\mathrm{CH}_{3}\right), \quad 11.89$ $\left(-\mathrm{CH}_{2} \mathrm{CH}_{3}\right)$. TG curve (Figure $\mathrm{S} 1$, Supporting Information): $>115$ ${ }^{\circ} \mathrm{C}$ gradual dec. When the colorless cis- $[\mathrm{Pt}(\mathrm{tmeda})\{\mathrm{NH}=\mathrm{C}$ $\left.\left.\left(\mathrm{NH}_{2}\right) \mathrm{Et}\right\}_{2}\right]\left[\mathrm{SO}_{3} \mathrm{CF}_{3}\right]_{2}$ was heated in the solid phase at $200{ }^{\circ} \mathrm{C}$ for $12 \mathrm{~h}$, the complex turned into a dark brown yet unidentified compound, which was characterized by ${ }^{1} \mathrm{H}$ NMR spectroscopy $\left(\mathrm{Me}_{2} \mathrm{CO}-d_{6}, \delta\right.$ ): 8.48 (s, br, 6H, NH), 3.06 (s, 4H, N-CH $\mathrm{CH}_{2}$, 2.99 $\left(\mathrm{s}, 12 \mathrm{H}, \mathrm{NCH}_{3}\right), 2.71\left(\mathrm{q}, J_{\mathrm{HH}}=7.3 \mathrm{~Hz}, 4 \mathrm{H},-\mathrm{CH}_{2} \mathrm{CH}_{3}\right), 1.36(\mathrm{t}$, $\left.J_{\mathrm{HH}}=7.3 \mathrm{~Hz}, 6 \mathrm{H},-\mathrm{CH}_{2} \mathrm{CH}_{3}\right)$.

cis-[Pt(tmeda) $\left.\left\{\mathrm{NH}=\mathrm{C}\left(\mathrm{NH}_{2}\right) \mathrm{Et}\right\}_{2}\right]\left[\mathrm{C}_{6} \mathrm{H}_{2} \mathrm{~N}_{3} \mathrm{O}_{7}\right]_{2}$ was obtained by mixing cis-[Pt(tmeda) $\left.\left\{\mathrm{NH}=\mathrm{C}\left(\mathrm{NH}_{2}\right) \mathrm{Et}\right\}_{2}\right]\left[\mathrm{SO}_{3} \mathrm{CF}_{3}\right]_{2}$ with a 2-fold excess of picric acid at room temperature in methanol solution, giving a yellow solution followed by slow evaporation at room temperature to furnish crystals suitable for X-ray crystallography. Caution! Picrate salts of metal complexes are potentially explosive!

$\mathbf{1 0} \cdot(\mathbf{O T f})_{\mathbf{2}} \cdot \mathbf{H}_{\mathbf{2}} \mathbf{O} \cdot \mathrm{HN}=\mathrm{C}(\mathrm{NHPh})_{2}(0.06 \mathrm{~g}, 0.28 \mathrm{mmol})$ was added to a solution of cis-[Pt(tmeda) $\left.(\mathrm{EtCN})_{2}\right]\left[\mathrm{SO}_{3} \mathrm{CF}_{3}\right]_{2}$ [prepared from cis-[ $\left[\mathrm{PtI}_{2}\right.$ (tmeda) $(0.14 \mathrm{mmol})$ as described above] in $\mathrm{CH}_{2} \mathrm{Cl}_{2}(2$ $\mathrm{mL}$ ) and the reaction mixture was stirred for $6 \mathrm{~h}$ at room temperature. A lilac residue formed was thoroughly washed (with decantation) with small portions of $\mathrm{Et}_{2} \mathrm{O}$ and $\mathrm{CHCl}_{3}$ to avoid dissolution of the target product. Yield is $0.05 \mathrm{~g}, 46 \%$.

Anal. Calcd for $\mathrm{PtC}_{14} \mathrm{H}_{29} \mathrm{~N}_{5} \mathrm{~F}_{6} \mathrm{~S}_{2} \mathrm{O}_{6} \cdot \mathrm{H}_{2} \mathrm{O}$ : C, 22.28; H, 4.14; N, 9.28. Found C, 22.57; H, 4.25; N, 9.33. ESI ${ }^{+}-\mathrm{MS}(\mathrm{m} / \mathrm{z}): 437$ [M $\mathrm{H}]^{+}$. IR (KBr, selected bands, $\left.\mathrm{cm}^{-1}\right): 3439(\mathrm{~m}), 3269(\mathrm{~m}), v(\mathrm{~N}-\mathrm{H})$; $2831(\mathrm{~m}-\mathrm{w}), v(\mathrm{C}-\mathrm{H}$ from $\mathrm{Et}) ; 1610(\mathrm{~s}), 1547(\mathrm{~s}), v(\mathrm{C}=\mathrm{N}) ; 1224$ $(\mathrm{s}), 1163(\mathrm{~s}), 1030(\mathrm{~s}), v(\mathrm{C}-\mathrm{N}$ from the 1,3,5-triazapentadiene and/ or tmeda). ${ }^{1} \mathrm{H}$ NMR $\left(\mathrm{Me}_{2} \mathrm{CO}-d_{6}, \delta\right): 10.94(\mathrm{~s}, \mathrm{br}, 1 \mathrm{H},-\mathrm{NH}-)$, 9.22 (s, br, $2 \mathrm{H},-\mathrm{NH}=\mathrm{C}-$ ) $, 3.23\left(\mathrm{~s}, 4 \mathrm{H}, \mathrm{N}-\mathrm{CH}_{2}\right), 3.17(\mathrm{~s}, 12 \mathrm{H}$, $\left.\mathrm{N}-\mathrm{CH}_{3}\right), 2.83\left(\mathrm{q}, J_{\mathrm{HH}}=7.3 \mathrm{~Hz}, 4 \mathrm{H},-\mathrm{CH}_{2} \mathrm{CH}_{3}\right), 1.32\left(\mathrm{t}, J_{\mathrm{HH}}=\right.$ $\left.7.3 \mathrm{~Hz}, 6 \mathrm{H},-\mathrm{CH}_{2} \mathrm{CH}_{3}\right) .{ }^{13} \mathrm{C}\left\{{ }^{1} \mathrm{H}\right\}$ NMR $\left(\mathrm{Me}_{2} \mathrm{CO}-d_{6}, \delta\right): 163.81$ $(\mathrm{C}=\mathrm{N}), 64.94\left(\mathrm{~N}-\mathrm{CH}_{2}\right), 52.26\left(\mathrm{~N}-\mathrm{CH}_{3}\right), 11.56\left(-\mathrm{CH}_{2} \mathrm{CH}_{3}\right)$.

$[\mathrm{Pt}($ tmeda $)\{N \mathrm{HC}(\mathrm{Et}) \mathrm{NHC}(\mathrm{Et}) N \mathrm{H}\}]\left[\mathrm{C}_{6} \mathrm{H}_{2} \mathrm{~N}_{3} \mathrm{O}_{7}\right]_{2}$ was obtained by mixing the $c i s-[\mathrm{Pt}(\mathrm{tmeda})\{N \mathrm{HC}(\mathrm{Et}) \mathrm{NHC}(\mathrm{Et}) N \mathrm{H}\}]\left[\mathrm{SO}_{3} \mathrm{CF}_{3}\right]_{2}$ complex with a 2-fold excess of picric acid at room temperature in methanol solution, giving a yellow solution followed by its slow evaporation at room temperature to furnish crystals suitable for X-ray crystallography. Caution! Picrate salts of metal complexes are potentially explosive!

Attempted Reaction between $10 \cdot(\mathrm{OTf})_{2} \cdot \mathrm{H}_{2} \mathrm{O}$ and Ammonia. The complex $(20 \mathrm{mg})$ was dissolved in $\mathrm{MeOH}(2 \mathrm{~mL})$. The obtained solution was stirred under an atmosphere of gaseous ammonia at $20-25{ }^{\circ} \mathrm{C}$ for $6 \mathrm{~h}$, whereupon the solvent was evaporated to dryness at room temperature under vacuum, redissolved in $\mathrm{Me}_{2} \mathrm{CO}-d_{6}$, and characterized by ${ }^{1} \mathrm{H}$ NMR spectroscopy. The obtained spectrum corresponds to the intact $\mathbf{1 0} \cdot(\mathrm{OTf})_{2}$, and

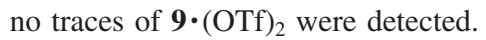

Reaction of trans-[ $\left.\mathbf{P t C l}_{2}(\mathbf{R C N})_{2}\right]$ and DPG (2 equiv). trans$\left[\mathrm{PtCl}_{2}(\mathrm{RCN})_{2}\right]\left(\mathrm{R}=\mathrm{Et}, \mathrm{CH}_{2} \mathrm{Ph}, \mathrm{Ph}\right)(0.12 \mathrm{mmol})$ and $\mathrm{HN}=$ $\mathrm{C}(\mathrm{NHPh})_{2}(50.7 \mathrm{mg}, 0.24 \mathrm{mmol})$ were dissolved in $\mathrm{EtCN}(1 \mathrm{~mL})$ $(\mathrm{R}=\mathrm{Et})$ or $\mathrm{CH}_{2} \mathrm{Cl}_{2}(1 \mathrm{~mL})\left(\mathrm{R}=\mathrm{CH}_{2} \mathrm{Ph}, \mathrm{Ph}\right)$ and left to stand for $24 \mathrm{~h}(\mathrm{R}=\mathrm{Et})$ or $15 \mathrm{~h}\left(\mathrm{R}=\mathrm{CH}_{2} \mathrm{Ph}, \mathrm{Ph}\right)$ at $20-25^{\circ} \mathrm{C}$. The yellow solutions $\left(\mathrm{R}=\mathrm{Et}, \mathrm{CH}_{2} \mathrm{Ph}, \mathrm{Ph}\right)$ were evaporated to dryness. The pale yellow solid residue for $\mathrm{R}=\mathrm{Et}$ was washed with one $0.5 \mathrm{~mL}$ portion of $\mathrm{MeOH}$, filtered off, washed with one $0.5 \mathrm{~mL}$ portion of $\mathrm{Et}_{2} \mathrm{O}$, and dried in air at $20-25^{\circ} \mathrm{C}$. Products for $\mathrm{R}=\mathrm{CH}_{2} \mathrm{Ph}, \mathrm{Ph}$ were separated from yellow oily residues by column chromatography on $\mathrm{SiO}_{2}$ (silica gel $60 \mathrm{~F}_{254}, 0.063-0.200 \mathrm{~mm}$, Merck; eluent 
$1 / 10 \mathrm{Et}_{2} \mathrm{O}-\mathrm{CHCl}_{3}\left(\mathrm{R}=\mathrm{CH}_{2} \mathrm{Ph}\right)$ or $1 / 20$ ethyl acetate $-\mathrm{CHCl}_{3}(\mathrm{R}$ $=\mathrm{Ph}$ ), first fractions) and washed with one $0.5 \mathrm{~mL}$ portion of $\mathrm{Et}_{2} \mathrm{O}$. Yields are $30 \mathrm{mg}, 45 \%(\mathrm{R}=\mathrm{Et}), 21 \mathrm{mg}, 26 \%\left(\mathrm{R}=\mathrm{CH}_{2} \mathrm{Ph}\right)$, and $15 \mathrm{mg}, 20 \%(\mathrm{R}=\mathrm{Ph})$.

11. Anal. Calcd for $\mathrm{C}_{19} \mathrm{H}_{22} \mathrm{~N}_{5} \mathrm{ClPt}$ : C, 41.42; H, 4.02; N, 12.71 . Found: C, 41.89; H, 4.19; N, 12.78. $\mathrm{FAB}^{+}-\mathrm{MS}(\mathrm{m} / \mathrm{z}): 550[\mathrm{M}]^{+}$, $515[\mathrm{M}-\mathrm{Cl}]^{+}, 495[\mathrm{M}-\mathrm{EtCN}]^{+}, 459[\mathrm{M}-\mathrm{HCl}-\mathrm{EtCN}]^{+}$. TLC: $R_{f}=0.39$ (eluent $1 / 20 \mathrm{Me}_{2} \mathrm{CO}-\mathrm{CHCl}_{3}$ ). IR (KBr, selected bands, $\left.\mathrm{cm}^{-1}\right)$ : $3456(\mathrm{~m}-\mathrm{w}), 3355(\mathrm{~m}-\mathrm{w}), v(\mathrm{~N}-\mathrm{H}) ; 1636(\mathrm{~s})$, $v(\mathrm{C}=\mathrm{N}) ; 1582(\mathrm{~s}), 1543(\mathrm{~s}), v(\mathrm{C}=\mathrm{N}$ and/or $\mathrm{C}=\mathrm{C}$ from $\mathrm{Ar}) .{ }^{1} \mathrm{H}$ NMR $\left(\mathrm{CDCl}_{3}, \delta\right): 7.47(\mathrm{t}, 2 \mathrm{H}), 7.30(\mathrm{~d}, 2 \mathrm{H}), 7.27-7.16(\mathrm{~m}, 5 \mathrm{H})$, $6.98(\mathrm{t}, 1 \mathrm{H})(\mathrm{Ph}), 6.64(\mathrm{~s}, \mathrm{br}, 1 \mathrm{H}), 5.87(\mathrm{~s}, 1 \mathrm{H})(\mathrm{NH}), 2.33(\mathrm{q}, 7.6$ $\mathrm{Hz}, 2 \mathrm{H}, \mathrm{CH}_{2}$ in $\left.\mathrm{N} \equiv \mathrm{CEt}\right), 2.16\left(\mathrm{q}, 7.6 \mathrm{~Hz}, 2 \mathrm{H}, \mathrm{CH}_{2}\right.$ in $\left.\mathrm{HN}=\mathrm{CEt}\right)$, $1.19\left(\mathrm{t}, 7.6 \mathrm{~Hz}, 3 \mathrm{H}, \mathrm{CH}_{3}\right.$ in $\left.\mathrm{N} \equiv \mathrm{CEt}\right), 0.94\left(\mathrm{t}, 7.6 \mathrm{~Hz}, 3 \mathrm{H}, \mathrm{CH}_{3}\right.$ in $\mathrm{HN}=\mathrm{C} E t) .{ }^{13} \mathrm{C}\left\{{ }^{1} \mathrm{H}\right\} \mathrm{NMR}\left(\mathrm{CDCl}_{3}, \delta\right): 164.91(\mathrm{C}=\mathrm{N}-\mathrm{H}), 148.68$, $147.00,139.87\left(\mathrm{C}=\mathrm{N}-\mathrm{Ph}\right.$ and/or $\left.C_{\text {ipso }}\right), 129.90,128.66,128.24$, 127.05, 123.47, 122.37 (carbons in $\mathrm{Ph}), 118.05(C \equiv \mathrm{N}), 33.34\left(\mathrm{CH}_{2}\right.$ in $\mathrm{HN}=\mathrm{CEt}), 12.09\left(\mathrm{CH}_{2}\right.$ in $\left.\mathrm{N} \equiv \mathrm{CEt}\right), 11.75\left(\mathrm{CH}_{3}\right.$ in $\left.\mathrm{HN}=\mathrm{CEt}\right)$, $9.54\left(\mathrm{CH}_{3}\right.$ in $\left.\mathrm{N} \equiv \mathrm{CEt}\right)$.

12. Anal. Calcd for $\mathrm{C}_{29} \mathrm{H}_{26} \mathrm{~N}_{5} \mathrm{ClPt}$ : C, 51.60; H, 3.88; N, 10.37 . Found: C, 51.64; H, 3.91; N, 10.38. FAB $^{+}-\mathrm{MS}(\mathrm{m} / \mathrm{z}): 676[\mathrm{M}+$ $\mathrm{H}]^{+}, 640[\mathrm{M}+\mathrm{H}-\mathrm{Cl}]^{+}, 558\left[\mathrm{M}-\mathrm{PhCH}_{2} \mathrm{CN}\right]^{+}, 522[\mathrm{M}-\mathrm{Cl}$ $\left.-\mathrm{PhCH}_{2} \mathrm{CN}\right]^{+}$. TLC: $R_{f}=0.64$ (eluent $1 / 10 \mathrm{Et}_{2} \mathrm{O}-\mathrm{CHCl}_{3}$ ). IR (KBr, selected bands, $\left.\mathrm{cm}^{-1}\right): 3408(\mathrm{~m}-\mathrm{w}), 3362(\mathrm{~m}-\mathrm{w}), 3332(\mathrm{~m}-$ $\mathrm{w}), v(\mathrm{~N}-\mathrm{H}) ; 3055(\mathrm{w}), 3026(\mathrm{w}), v(\mathrm{C}-\mathrm{H}$ from Ar); $2949(\mathrm{w}), 2916$ (w), $v\left(\mathrm{C}-\mathrm{H}\right.$ from $\left.\mathrm{CH}_{2} \mathrm{Ph}\right), 1598$ (m-s), $1570(\mathrm{~s}), v(\mathrm{C}=\mathrm{N}$ and/or $\mathrm{C}=\mathrm{C}$ from $\mathrm{Ar}) ; 746(\mathrm{~m}), 698(\mathrm{~m}-\mathrm{s}), \delta(\mathrm{C}-\mathrm{H}$ from $\mathrm{Ar}) .{ }^{1} \mathrm{H}$ NMR $\left(\mathrm{CDCl}_{3}, \delta\right): 7.36-7.23(\mathrm{~m}, 12 \mathrm{H}), 7.09(\mathrm{q}, 3 \mathrm{H}), 7.04-7.01(\mathrm{~m}, 4 \mathrm{H})$, $6.96(\mathrm{t}, 1 \mathrm{H})(\mathrm{Ph}$ 's), $6.76(\mathrm{~s}, \mathrm{br}, 1 \mathrm{H}), 5.85(\mathrm{~s}, 1 \mathrm{H})(\mathrm{NH}), 3.63(\mathrm{~s}$, $2 \mathrm{H}), 3.51(\mathrm{~s}, 2 \mathrm{H})\left(\mathrm{CH}_{2} \mathrm{Ph}\right) .{ }^{13} \mathrm{C}\left\{{ }^{1} \mathrm{H}\right\}$ NMR $\left(\mathrm{CDCl}_{3}, \delta\right): 162.62$ $(\mathrm{C}=\mathrm{N}-\mathrm{H}), 148.28,147.12,139.67,136.52\left(\mathrm{C}=\mathrm{N}-\mathrm{Ph}\right.$ and/or $\left.C_{\text {ipso }}\right)$, $130.09,129.90,129.65,129.00,128.67,128.46,128.01,127.56$, $127.33,127.05,123.40,122.21$ (carbons in $\mathrm{Ph}), 115.56(C \equiv \mathrm{N})$, 46.45, $24.39\left(\mathrm{CH}_{2} \mathrm{Ph}\right)$.

13. Anal. Calcd for $\mathrm{C}_{27} \mathrm{H}_{22} \mathrm{~N}_{5} \mathrm{ClPt}$ : C, 50.12; H, 3.43; N, 10.82 . Found: C, 50.44; H, 3.35; N, 10.76. $\mathrm{FAB}^{+}{ }_{-} \mathrm{MS}(\mathrm{m} / \mathrm{z}): 647[\mathrm{M}]^{+}$, $611[\mathrm{M}-\mathrm{Cl}]^{+}, 543\left[\mathrm{M}-\mathrm{PhCN}^{+}, 507[\mathrm{M}-\mathrm{HCl}-\mathrm{PhCN}]^{+}\right.$. TLC: $R_{f}=0.69$ (eluent $1 / 20 \mathrm{Me}_{2} \mathrm{CO}-\mathrm{CHCl}_{3}$ ). IR $(\mathrm{KBr}$, selected bands, $\left.\mathrm{cm}^{-1}\right)$ : 3396 (m-w), $3366(\mathrm{~m}-\mathrm{w}), v(\mathrm{~N}-\mathrm{H}) ; 3060$ (m-w), $v(\mathrm{C}-\mathrm{H}$ from $\mathrm{Ar}) ; 2274(\mathrm{w}), v(\mathrm{C} \equiv \mathrm{N}) ; 1594(\mathrm{~s}), 1560(\mathrm{~s}), 1519(\mathrm{~s})$, $\nu(\mathrm{C}=\mathrm{N}$ and/or $\mathrm{C}=\mathrm{C}$ from $\mathrm{Ar}) ; 752(\mathrm{~m}), 697(\mathrm{~m}-\mathrm{s}), \delta(\mathrm{C}-\mathrm{H}$ from Ar). ${ }^{1} \mathrm{H} \mathrm{NMR}\left(\mathrm{CDCl}_{3}, \delta\right): 7.88(\mathrm{~d}, 2 \mathrm{H}), 7.64(\mathrm{t}, 1 \mathrm{H}), 7.49-7.36$ $(\mathrm{m}, 12 \mathrm{H}), 7.30-7.19(\mathrm{~m}, 4 \mathrm{H}), 7.06(\mathrm{t}, 1 \mathrm{H})(\mathrm{Ph}), 6.50(\mathrm{~s}, 1 \mathrm{H}), 6.00$ $(\mathrm{s}, 1 \mathrm{H})(\mathrm{N} H) \cdot{ }^{13} \mathrm{C}\left\{{ }^{1} \mathrm{H}\right\}$ NMR $\left(\mathrm{CDCl}_{3}, \delta\right): 158.37(\mathrm{C}=\mathrm{N}-\mathrm{H})$, $148.69,147.95,139.84\left(\mathrm{C}=\mathrm{N}-\mathrm{Ph}\right.$ and/or $\left.C_{\mathrm{ipso}}\right), 134.58,133.29$, 130.72 , 130.13, 129.40, 128.86, 128.74, 128.17, 127.48, 127.21, 123.96, 123.29 (carbons in $\mathrm{Ph}), 110.26(C \equiv \mathrm{N})$.

Reaction of trans-[PtCl$\left(\mathrm{RCN}_{2}\right]$ and DPG $(4,6$, or 8 equiv). trans- $\left[\mathrm{PtCl}_{2}(\mathrm{RCN})_{2}\right]\left(\mathrm{R}=\mathrm{Et}, \mathrm{CH}_{2} \mathrm{Ph}, \mathrm{Ph}\right)(0.10 \mathrm{mmol})$ and $\mathrm{HN}=\mathrm{C}(\mathrm{NHPh})_{2}(85 \mathrm{mg}, 0.40 \mathrm{mmol}$ for 4 equiv, $127 \mathrm{mg}, 0.60 \mathrm{mmol}$ for 6 equiv, and $169 \mathrm{mg}, 0.80 \mathrm{mmol}$ for $\mathbf{8}$ equiv) were dissolved in the corresponding $\mathrm{RCN}(1 \mathrm{~mL})\left(\mathrm{R}=\mathrm{Et}, \mathrm{CH}_{2} \mathrm{Ph}, \mathrm{Ph}\right)$ and left to react with stirring for $48 \mathrm{~h}(\mathrm{R}=\mathrm{Et})$ or without stirring for $24 \mathrm{~h}(\mathrm{R}$ $=\mathrm{CH}_{2} \mathrm{Ph}, \mathrm{Ph}$ ) at $75^{\circ} \mathrm{C}$. The obtained colorless precipitate for $\mathrm{R}=$ Et was separated by decantation, washed with two $1.5 \mathrm{~mL}$ portions of $\mathrm{Me}_{2} \mathrm{CO}$ and one $1.5 \mathrm{~mL}$ portion of $\mathrm{Et}_{2} \mathrm{O}$, and dried in air at 20-25 ${ }^{\circ} \mathrm{C}$. The solution for $\mathrm{R}=\mathrm{CH}_{2} \mathrm{Ph}, \mathrm{Ph}$ was evaporated to dryness, and the colorless $\left(\mathrm{R}=\mathrm{CH}_{2} \mathrm{Ph}\right)$ or yellow $(\mathrm{R}=\mathrm{Ph})$ needlelike precipitate was washed with one $1 \mathrm{~mL}$ portion of $\mathrm{Me}_{2} \mathrm{CO}$, filtered off, washed with one $1 \mathrm{~mL}$ portion of $\mathrm{Me}_{2} \mathrm{CO}$ and one 1 $\mathrm{mL}$ portion of $\mathrm{Et}_{2} \mathrm{O}$, and dried in air at $20-25^{\circ} \mathrm{C}$. TG curves: 277 and $282{ }^{\circ} \mathrm{C}$ (for complexes $\mathbf{1 4}$ and $\mathbf{1 5}$, respectively) and $301{ }^{\circ} \mathrm{C}$ (for complex 16). Yields of complexes do not depend significantly on the amount of DPG (4, 6, or 8 equiv). Yields are $46 \mathrm{mg}, 63 \%$ $(\mathrm{R}=\mathrm{Et}), 62 \mathrm{mg}, 73 \%\left(\mathrm{R}=\mathrm{CH}_{2} \mathrm{Ph}\right)$, and $55 \mathrm{mg}, 67 \%(\mathrm{R}=\mathrm{Ph})$ (data for reactions performed with trans- $\left[\mathrm{PtCl}_{2}(\mathrm{RCN})_{2}\right]$ and 4 equiv of DPG).

14. Anal. Calcd for $\mathrm{C}_{32} \mathrm{H}_{34} \mathrm{~N}_{8} \mathrm{Pt}$ : C, 53.00; H, 4.70; N, 15.41 . Found: C, 53.61; H, 4.87; N, 15.65. $\mathrm{FAB}^{+}-\mathrm{MS}(\mathrm{m} / \mathrm{z}): 726[\mathrm{M}]^{+}$. TLC: $R_{f}=0.53$ (eluent $1 / 4 \mathrm{Me}_{2} \mathrm{CO}-\mathrm{CHCl}_{3}$ ). DTA/TG: $277{ }^{\circ} \mathrm{C}$ (gradual dec). IR ( $\mathrm{KBr}$, selected bands, $\left.\mathrm{cm}^{-1}\right)$ : 3420 (m-s), 3355 (m-s), $v(\mathrm{~N}-\mathrm{H}) ; 3093(\mathrm{w}), 3057$ (m-w), 3023 (m-w), v(C-H from Ar); 2962 (m), 2935 (m-w), 2908 (m-w), 2875 (m-w), 2825 (w), $2779(\mathrm{w}), v(\mathrm{C}-\mathrm{H}$ from Et); $1596(\mathrm{~s}), 1571(\mathrm{~s}), 1538(\mathrm{~m}-\mathrm{s}), v(\mathrm{C}=\mathrm{N}$ and/or $\mathrm{C}=\mathrm{C}$ from $\mathrm{Ar}) ; 749$ (m-s), $702(\mathrm{~s}), \delta(\mathrm{C}-\mathrm{H}$ from $\mathrm{Ar}) .{ }^{1} \mathrm{H}$ $\mathrm{NMR}\left(\mathrm{CDCl}_{3}, \delta\right): 7.56(\mathrm{t}, 4 \mathrm{H}), 7.38-7.28(\mathrm{~m}, 6 \mathrm{H}), 7.21-7.12(\mathrm{~m}$, $8 \mathrm{H}), 6.93(\mathrm{t}, 2 \mathrm{H})(\mathrm{Ph}), 5.81(\mathrm{~s}, \mathrm{br}, 2 \mathrm{H}), 4.88(\mathrm{~s}, \mathrm{br}, 2 \mathrm{H})(\mathrm{NH}), 1.92$ $(\mathrm{q}, 7.5 \mathrm{~Hz}, 4 \mathrm{H})$, and $0.71(\mathrm{t}, 7.5 \mathrm{~Hz}, 6 \mathrm{H})(E t) .{ }^{13} \mathrm{C}\left\{{ }^{1} \mathrm{H}\right\} \mathrm{NMR}$ $\left(\mathrm{CDCl}_{3}, \delta\right): 165.04(\mathrm{C}=\mathrm{N}-\mathrm{H}), 147.64,144.91,140.55(\mathrm{C}=\mathrm{N}-\mathrm{Ph}$ and/or $\left.C_{\text {ipso }}\right), 130.83,128.83,128.58,127.26,122.80,121.89$ (carbons in $\mathrm{Ph}), 33.68\left(\mathrm{CH}_{2}\right)$, and $10.50\left(\mathrm{CH}_{3}\right)(\mathrm{Et})$.

15. Anal. Calcd for $\mathrm{C}_{42} \mathrm{H}_{38} \mathrm{~N}_{8} \mathrm{Pt}$ : C, 59.36; H, 4.51; N, 13.18 . Found: C, 59.59; H, 4.55; N, 13.55. FAB ${ }^{+}-\mathrm{MS}(\mathrm{m} / \mathrm{z}): 849[\mathrm{M}]^{+}$. TLC: $R_{f}=0.45$ (eluent $1 / 10 \mathrm{Et}_{2} \mathrm{O}-\mathrm{CHCl}_{3}$ ). DTA/TG: $282{ }^{\circ} \mathrm{C}$ (gradual dec). IR (KBr, selected bands, $\mathrm{cm}^{-1}$ ): 3413 (m-s), 3338 (m-s), $v(\mathrm{~N}-\mathrm{H}) ; 3057$ (m-w), 3029 (m-w), $v(\mathrm{C}-\mathrm{H}$ from Ar); 2954 (w), 2928 (w), $v\left(\mathrm{C}-\mathrm{H}\right.$ from $\left.\mathrm{CH}_{2} \mathrm{Ph}\right) ; 1602$ (s), 1572 (s), 1538 (m$\mathrm{s}), v(\mathrm{C}=\mathrm{N}$ and/or $\mathrm{C}=\mathrm{C}$ from $\mathrm{Ar}) ; 749(\mathrm{~m}-\mathrm{s}), 702(\mathrm{~s}), \delta(\mathrm{C}-\mathrm{H}$ from Ar). ${ }^{1} \mathrm{H} \mathrm{NMR}\left(\mathrm{CDCl}_{3}, \delta\right): 7.43(\mathrm{t}, 4 \mathrm{H}), 7.27-7.20(\mathrm{~m}, 11 \mathrm{H})$, 7.11-6.99 (m, 13H), $6.91(\mathrm{t}, 2 \mathrm{H})(\mathrm{Ph}), 5.75(\mathrm{~s}, \mathrm{br}, 2 \mathrm{H}), 4.81(\mathrm{~s}, \mathrm{br}$, $2 \mathrm{H})(\mathrm{NH}), 3.12\left(\mathrm{~s}, 4 \mathrm{H}, \mathrm{CH}_{2} \mathrm{Ph}\right)$. The compound is poorly soluble in all common deuterated solvents, and this precluded ${ }^{13} \mathrm{C}\left\{{ }^{1} \mathrm{H}\right\}$ NMR measurements.

16. Anal. Calcd for $\mathrm{C}_{40} \mathrm{H}_{34} \mathrm{~N}_{8} \mathrm{Pt}$ : C, 58.46; H, 4.17; N, 13.63. Found: C, 58.12; H, 4.17; N, 13.12\%. $\mathrm{FAB}^{+}{ }_{-} \mathrm{MS}(\mathrm{m} / \mathrm{z}): 822[\mathrm{M}+$ $\mathrm{H}]^{+}$. TLC: $R_{f}=0.41$ (eluent $1 / 20 \mathrm{Et}_{2} \mathrm{O}-\mathrm{CHCl}_{3}$ ). DTA/TG: 302 ${ }^{\circ} \mathrm{C}$ (gradual dec). IR ( $\mathrm{KBr}$, selected bands, $\mathrm{cm}^{-1}$ ): 3422 (m), 3366 (m), $v(\mathrm{~N}-\mathrm{H}) ; 3057$ (m-w), $v(\mathrm{C}-\mathrm{H}$ from $\mathrm{Ar}) ; 1590$ (m-s), 1558 (s), $1522(\mathrm{~m}-\mathrm{s}), v(\mathrm{C}=\mathrm{N}$ and/or $\mathrm{C}=\mathrm{C}$ from $\mathrm{Ar}) ; 749(\mathrm{~m}), 694(\mathrm{~m}-$ $\mathrm{s}), \delta\left(\mathrm{C}-\mathrm{H}\right.$ from Ar). ${ }^{1} \mathrm{H}$ NMR $\left(\mathrm{CDCl}_{3}, \delta\right): 7.65(\mathrm{t}, 4 \mathrm{H}), 7.45(\mathrm{~d}$, $6 \mathrm{H}), 7.35(\mathrm{t}, 2 \mathrm{H}), 7.24-7.13(\mathrm{~m}, 16 \mathrm{H}), 7.01(\mathrm{t}, 2 \mathrm{H})(\mathrm{Ph}), 5.91(\mathrm{~s}$, $2 \mathrm{H}), 5.68(\mathrm{~s}, \mathrm{br}, 2 \mathrm{H})(\mathrm{NH})$. The compound is poorly soluble in all common deuterated solvents, and this precluded ${ }^{13} \mathrm{C}\left\{{ }^{1} \mathrm{H}\right\}$ NMR measurements.

Acknowledgment. This work has been supported by the Russian Fund for Basic Research (Grant 08-03-90100) and also by the bilateral RFBR-NSF (Taiwan) Grant 07-0392002. M.-J.W. and V.Yu.K. express their gratitude to the National Taiwan University of Science and Technology for the Cooperation Grant NTUST-2007-R-01 and for the Visiting Chair Professorship provided for V.Yu.K. M.H. and V.Yu.K. thank the Academy of Finland for financial support (Grant 121266). We are very much obliged to Dr. A. A. Nazarov for running ESI mass spectra and Prof. D. Osella for the synthetic procedure for $\left[\mathrm{PtI}_{2}(\mathrm{tmeda})\right]$.

Supporting Information Available: Figure S1, giving the TG curve for $\mathbf{9} \cdot(\mathrm{OTf})_{2}$, Figures S2-S4, giving molecular structures of $\mathbf{1}, \mathbf{2}$, and 11, Figure S5, giving the hydrogen-bonding scheme for 4, Table S1, giving the hydrogen bonds for $\mathbf{4}$, CIF files giving crystallographic data, and text giving a detailed description of the synthetic procedure for $c i s-\left[\mathrm{PtI}_{2}(\mathrm{tmeda})\right]$ (7). This material is available free of charge via the Internet at http://pubs.acs.org.

IC702483W 